\title{
Second Generation Bioethanol Production: On the Use of Pulp and Paper Industry Wastes as Feedstock
}

\author{
Rita H. R. Branco, Luísa S. Serafim ${ }^{\circledR}$ and Ana M.R.B. Xavier *®D \\ CICECO-Aveiro Institute of Materials, Chemistry Department, University of Aveiro, Campus Universitario de \\ Santiago, 3810-193 Aveiro, Portugal; rebola@ua.pt (R.H.R.B.); luisa.serafim@ua.pt (L.S.S.) \\ * Correspondence: abx@ua.pt; Tel.: +351-234-370-716
}

Received: 30 October 2018; Accepted: 19 December 2018; Published: 24 December 2018

\begin{abstract}
Due to the health and environment impacts of fossil fuels utilization, biofuels have been investigated as a potential alternative renewable source of energy. Bioethanol is currently the most produced biofuel, mainly of first generation, resulting in food-fuel competition. Second generation bioethanol is produced from lignocellulosic biomass, but a costly and difficult pretreatment is required. The pulp and paper industry has the biggest income of biomass for non-food-chain production, and, simultaneously generates a high amount of residues. According to the circular economy model, these residues, rich in monosaccharides, or even in polysaccharides besides lignin, can be utilized as a proper feedstock for second generation bioethanol production. Biorefineries can be integrated in the existing pulp and paper industrial plants by exploiting the high level of technology and also the infrastructures and logistics that are required to fractionate and handle woody biomass. This would contribute to the diversification of products and the increase of profitability of pulp and paper industry with additional environmental benefits. This work reviews the literature supporting the feasibility of producing ethanol from Kraft pulp, spent sulfite liquor, and pulp and paper sludge, presenting and discussing the practical attempt of biorefineries implementation in pulp and paper mills for bioethanol production.
\end{abstract}

Keywords: bioethanol; pulp and paper industry; lignocellulosic biomass; kraft pulp; spent sulfite liquor; pulp and paper sludge

\section{Introduction}

The world depends on nonrenewable energy sources for transport, heat and/or power generation. Fossil fuels are currently the main energy source, providing an estimated $78.4 \%$ of the global final energy consumption [1]. Due to the growing energy requirements and impacts of fossil fuels utilization on health and environment, there is a pressing need to find alternatives [2]. Also, based on the present use, the discovery rate of fossil fuels, soon, will not match the consumption rate [3]. Biofuels are a potential renewable energy source to replace fossil fuels, particularly due to the much lower greenhouse gases (GHG) emissions. Additionally, biofuels are produced from common biomass sources that are geographically more evenly distributed than fossil fuels, which allow for an autonomous and secure energy supply $[4,5]$. For these reasons, there is a rising interest in biofuels by the scientific community, with a growing number of articles being published on this topic [6].

Bioethanol is currently the most produced biofuel, corresponding to about $73 \%$ of the 135.3 billion liters of biofuel produced in 2016. The United States (USA) is the biggest producer, 59\%, followed by Brazil, which is responsible for $27 \%$ of the global production [1]. Bioethanol can be used as pure gasoline replacement or in blends with gasoline. The use of bioethanol in spark ignition engines has many advantages when compared with gasoline. Ethanol has a higher oxygen content, which promotes better combustion and lower exhaust emissions, and a higher octane number, which allows engines 
to operate at a higher compression ratio. Also, using vegetable biomass as feedstock for bioethanol production allows for recycling the $\mathrm{CO}_{2}$ released during combustion, reducing the $\mathrm{CO}_{2}$ emissions $[7,8]$. Bioethanol can be also used as a platform chemical for several molecules (e.g., diethyl ether, ethylene, propylene, acetaldehyde, and ethyl acetate), in beverages, pharmaceuticals, and cosmetics $[9,10]$. Nowadays, the commercial bioethanol is almost entirely of first generation since food crops are used as feedstock: sugarcane in Brazil, corn in the US, and wheat and sugar beet in the European Union (EU). The main disadvantage of first generation bioethanol is the competition over the utilization of arable land for cultivation of food crops between biofuel feedstocks, thus resulting on the increase of food prices [11-13].

Alternatively to the first generation, second generation bioethanol can be produced from residual biomass, such as forest, industrial, or municipal wastes. These feedstocks do not raise concerns about food sustainability, have a low and stable price, and practically do not demand extra land. Among these feedstocks is lignocellulosic biomass (LCB) that comprises different types of biomass, such as energy crops (e.g., perennial grasses), agricultural residues (e.g., wheat straw, corn stover, and sugarcane bagasse), and forest materials (mainly woody materials) [14]. In some countries, second generation bioethanol is already produced in a commercial-scale. Nevertheless, the large-scale production still faces some challenges to reduce the production costs, and an improvement on technology efficiency for the generation of commercial profit is still necessary [15]. In 2016, 58 billion liters of bioethanol were produced in the US, but solely around 38 million liters of second generation ethanol $[1,16]$. In the same year, in the EU, 5127 million liters of bioethanol were produced, but less than 1\% corresponded to second generation bioethanol [17]. In Brazil, 25,580 million liters of bioethanol were produced in 2016, with only six million liters of cellulosic origin, meaning that second generation ethanol was even more insignificant, less than $0.05 \%$ [18].

The global pulp and paper industry is one of the largest industries in the world, with about 400 million tonnes of paper and paperboard and 188 million tonnes of virgin pulp being produced in 2015 [19,20]. Pulp and paper industry is the major global consumer of woody biomass, and consequently, pulp and paper mills present the infrastructure and logistics that are required to handle LCB and generate a high amount of wastes. Chemical mills employ technology, developed over the last 150 years, which is capable of fractioning and converting LCB [21,22]. Hence, integrated biorefineries could be implemented in the existing pulp and paper mills for the production of bioethanol from wastes and by-products generated. This is a promising approach as it valorizes wastes and by-products and diversifies products, increasing the profitability of pulp and paper industry. Additionally, since one of the major limitations for the production of second generation bioethanol is the high capital investment cost, by using the existing equipment of pulp and paper industry, the economics of the process could be improved, and consequently, its opportunity to success could increase [23,24]. Among the different wastes of pulp and paper industry that can be used for bioethanol production are low-quality Kraft pulp [23], spent sulfite liquors [25], and pulp and paper sludge [26].

The implementation of biorefineries can help to solve the worldwide problem of the increasing amount of wastes. Biorefineries apply zero-waste conversion technologies, since wastes are used as raw materials $[27,28]$. Biorefining is the best way to achieve a large-scale sustainable use of biomass in bioeconomy and is a crucial part of circular economy, as it closes the cycles of biomass, water, and carbon through the co-production of food/feed ingredients, biobased products, and bioenergy from renewable resources in a clean and efficient way, maximizing biomass valorization $[29,30]$. The current world economy is based on a linear and open-ended system only concerned in meeting the current generation needs, compromises the ability of future generations to meet theirs, which is unsustainable. Circular economy addresses this sustainability issue, since it proposes a cyclical material and energy flow model [31].

This paper starts with a brief description of LCB composition with a focus on wood, followed by an overview of second generation bioethanol production, and then by the synthesis of the production of bioethanol from different pulp and paper industry wastes, namely Kraft pulp, spent sulfite liquors, 
and pulp and paper sludge. Finally, the future conversion of pulp and paper mills into biorefineries will be addressed before future prospects and conclusions of this revision work.

\section{Lignocellulosic Biomass Composition}

In general, LCB is composed by cellulose (30-60\%), hemicelluloses (20-40\%), and lignin (15-25\%), and small amounts of extractives and ashes [7]. Cellulose and hemicelluloses are polysaccharides that can be hydrolyzed to fermentable sugars, which can be converted to bioethanol. Lignin is not used for bioethanol production but it is a source of high value-added aromatic products [32].

Cellulose is a linear unbranched homopolysaccharide that is composed by monomers of D-glucose linked by $\beta-(1,4)$-glycosidic bonds. Its fibers are linked by intra- and inter-molecular hydrogen bonds, resulting in a highly ordered crystalline structure. The crystalline regions are interrupted by amorphous regions [33,34]. Hemicelluloses are shorter and highly branched heteropolysaccharides that are composed by different monomers that include pentoses (e.g., xylose, and arabinose), hexoses (e.g., mannose, glucose, galactose) and/or uronic acids (e.g., glucuronic, and galacturonic acids). Different polysaccharides can compose hemicelluloses, like glucomannan, galactoglucomannan, and xylan. Hemicelluloses are mostly amorphous. Lignin is an amorphous, highly hydrophobic, non-polysaccharide polymer matrix. It is a polyphenolic compound with undefined molecular mass and it is composed mainly by p-hydroxyphenyl, guaiacyl, and syringyl structural units linked by ether linkages and also with carbon-carbon bonds between these structural units, giving lignin a complex irregular structure [33-35]. Cellulose, hemicelluloses, and lignin are bonded by non-covalent bonds and covalent cross-linkages, interacting closely with each other in a strong and intermeshed network [36].

\section{Wood Composition}

All over the world, forests occupy a significant area, making wood from forest trees the major renewable resource on Earth. Wood is a raw material of great importance for mankind development since prehistoric times, as construction material and for thermal energy production $[37,38]$. Wood constitutes the cell wall of all woody species and can be classified as softwood, from gymnosperms (i.e., conifers), like pine, spruce, and fir, or as hardwood, from angiosperms (i.e., deciduous), such as birch, beech, oak, and poplar [38]. Table 1 shows the chemical composition of soft- and hardwoods.

Table 1. Chemical composition of soft- and hardwoods, adapted from [39].

\begin{tabular}{ccc}
\hline \multirow{2}{*}{ Compound } & \multicolumn{2}{c}{ Chemical Composition (\%) } \\
\cline { 2 - 3 } & Softwood & Hardwood \\
\hline Cellulose & $40-44$ & $45-50$ \\
Hemicelluloses & $25-29$ & $25-35$ \\
Lignin & $26-31$ & $18-24$ \\
\hline
\end{tabular}

While cellulose has a quite uniform composition in all woods, lignin, and hemicellulloses show some differences. Softwood lignin is composed mainly by guaiacyl units, while the lignin from hardwoods contains both guaiacyl and syringyl units [40]. When compared with softwood, hardwood lignin contains less carbon-carbon and more ether linkages between units [41]. The main polysaccharide present in hardwood hemicelluloses are glucuronoxylans (15-35\%), while glucomannans dominate in softwood hemicelluloses (10-15\%) [38].

\section{Second Generation Bioethanol Production}

Generally, the conversion of LCB to bioethanol usually starts with a preliminary step of feedstock preparation that involves cleaning and size reduction by milling, grinding, or chopping, consuming a large amount of energy [8,42]. Subsequently, the process follows four major steps as shown in Figure 1 [43,44]: Pretreatment, to degrade lignocellulosic network into its fractions; 
Hydrolysis/Saccharification, to obtain fermentable sugars; Fermentation, to convert sugars into ethanol; and, Recovery and dehydration, to separate and purify the obtained ethanol.

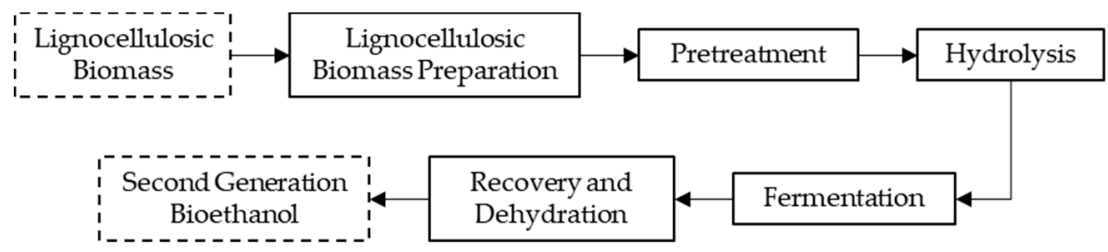

Figure 1. Steps for the conversion of lignocellulosic biomass (LCB) into bioethanol.

\subsection{Pretreatment}

Cellulose and hemicelluloses must be hydrolyzed to simple sugars before fermentation [45]. Hemicelluloses and lignin are strongly linked to cellulose and decrease the accessibility of the hydrolysis agent. Also, the crystalline structure of cellulose represents a higher resistance to hydrolysis, and the presence of lignin limits enzymatic hydrolysis due to the adsorption of enzymes [36]. Therefore, several pretreatments were developed to disrupt the compact and complex structure of LCB, changing both its micro- and macro-structure. Pretreatment performs delignification, i.e., it breaks down and removes lignin. Additionally, in this process, the degradation of hemicelluloses and the decrease of cellulose crystallinity should also occur $[35,46]$. Pretreatments can be classified as physical (e.g., milling, grinding, and microwave), chemical (acid, alkali, ozonolysis, organosolv, and ionic liquids), physicochemical (steam explosion, ammonia fiber explosion, $\mathrm{CO}_{2}$ explosion, liquid hot water, and wet oxidation), or biological [33,45].

The pretreatment is considered to be the main bottleneck of the development of a cost-effective bioethanol production from LCB, accounting for about $40 \%$ of the total cost [46]. Also, during pretreatment, LCB derivated compounds can be generated, which often have an inhibitory effect on enzymes and microorganisms, decreasing the sugar yield of hydrolysis and negatively affecting the biocatalytic processes of fermentation. The formation of these degradation products depends on the type of raw material, the pretreatment method, and the experimental conditions chosen [47]. These inhibitors include (i) furfural and HMF (5-hydroxymethyl-2-furaldehyde), from the degradation of hexoses and pentoses, respectively, which can be further degraded to formic and levulinic acid; (ii) acetic acid originated from hemicelluloses; and, (iii) phenolic compounds from lignin degradation [48]. Furans, i.e., furfural and HMF, inhibit microbial growth and increase the lag phase, decreasing the volumetric ethanol yield and productivity [49]. Low molecular weight organic acids such as acetic, formic, lactic, and levulinic acids are toxic to microorganisms and can affect their growth [47], since they can be transported through cell membrane acidifying the cytoplasm depending on intracellular $\mathrm{pH}$ and dissolved oxygen concentration [4,50]. Phenolic compounds like vanillin, syringaldehyde, trans-cinnamic acid, and hydroxybenzoic acid, were reported to inhibit cellulases [51].

Several detoxification technologies to remove inhibitors were already developed: physical—evaporation, extraction, and adsorption; (ii) chemical—neutralization, alkaline detoxification, and ionic exchange; and, (iii) biological—enzymatic and microbial detoxification. Nevertheless, these technologies represent an additional cost [52]. Other strategies were studied to solve or decrease the amount of inhibitory compounds, or, at least, reduce their effect. These strategies include the selection of a feedstock with a lower lignin amount and/or the genetic engineering of the vegetable species in order to reduce the amount of lignin. Another possibility is the selection of microorganisms with high resistance to inhibitors. The adaptive evolution of microorganisms to inhibitors and/or genetic and metabolic engineering to increase their resistance to inhibitors is also being investigated. Nevertheless, the inhibition of enzymes and microorganisms by LCB derivative compounds is a bottleneck that still needs to be studied [47,48]. 


\subsection{Hydrolysis/Saccharification}

Hydrolysis, also known as saccharification, is a crucial step as it converts the cellulose and hemicelluloses in their monomers, i.e., fermentable sugars. This can be achieved either biologically (enzymatic hydrolysis) or chemically (acidic hydrolysis) [53,54].

\subsubsection{Acidic Hydrolysis}

Acidic hydrolysis commonly involves the use of sulphuric or hydrochloric acids to break down cellulose and hemicelluloses. Concentrated acidic hydrolysis can be performed at low temperatures and a high sugar yield is obtained (i.e., $90 \%$ of the theoretical glucose yield) [55]. However, it requires high acid concentrations, usually in the range of 30-70\%, which leads to equipment corrosion. Therefore, concentrated acidic hydrolysis entails economic and environmental problems [56]. Conversely, diluted acidic hydrolysis requires a much lower amount of acid, $2-5 \%$, and it is more commonly applied in industry [55,57]. However, it requires a temperature around $200^{\circ} \mathrm{C}$, which can lead to the formation of different inhibitory compounds, such as acetic acid, furfural, HMF, and phenols. These compounds not only negatively affect the following fermentation step but also decrease the sugar yield [53,56].

\subsubsection{Enzymatic Hydrolysis}

Hydrolysis can be catalyzed by highly specific enzymes that are able to convert the complex carbohydrates of LCB to simple monomers. Enzymatic hydrolysis requires mild temperature and $\mathrm{pH}$ conditions (i.e., $50-60{ }^{\circ} \mathrm{C}$ and $\mathrm{pH} 4.5-5.5$ ). These conditions require less energy and they do not lead to the formation of inhibitory compounds or to equipment corrosion [58,59]. Most importantly, enzymatic hydrolysis attains high yields of sugars, $80-95 \%$, and has a reduced environmental impact [57]. The cost of enzymes, which is estimated to account for about $20 \%$ of the ethanol production costs, is still a major limitation of enzymatic hydrolysis [59]. Another disadvantage of using enzymes is the slowness of reactions, which results in long hydrolysis times (e.g., 1.5 days) [57].

Cellulases and hemicellulases are the enzymes that are usually employed for the hydrolysis of the LCB [60]. Cellulases, for cellulose hydrolysis, usually comprise three complementary groups of enzymes that are able to hydrolyze the $\beta$-(1,4)-glycosidic bonds: endoglucanases (EG), cellobiohydrolases (CBH), and $\beta$-glucosidases (BG) [61]. EG (endo-1,4- $\beta$-D-glucanases, EC 3.2.1.4) cleave the amorphous regions of cellulose. CBH (exo-1,4- $\beta$-D-glucanases, EC 3.2.1.91) hydrolyse the free ends of cellulose chain into the disaccharide cellobiose and are divided in $\mathrm{CBHI}$ and $\mathrm{CBHII}$ that act on the reducing and non-reducing ends, respectively. BG (EC 3.1.1.21) hydrolyze cellobiose to produce glucose [59,62]. These groups of enzymes are usually obtained at the industrial level from fungus Trichoderma resei [63]. Figure 2 describes the action of the different enzymes in cellulose hydrolysis.

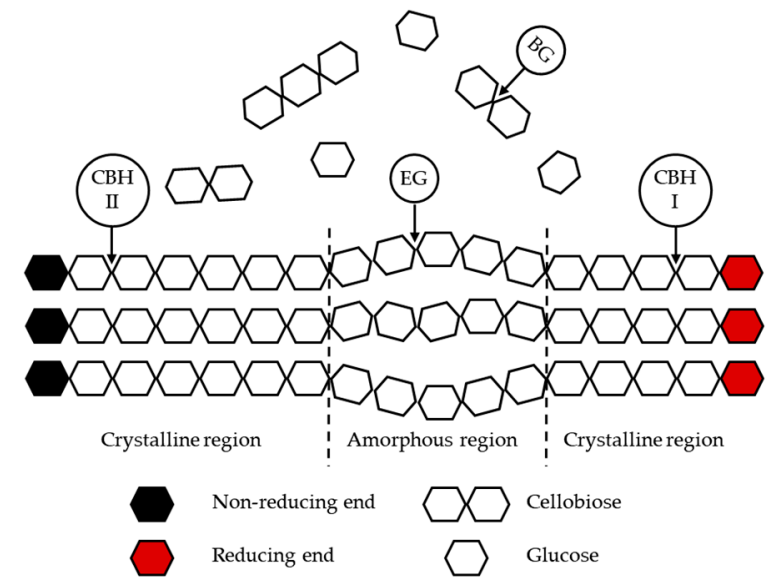

Figure 2. Schematic representation of the enzymatic hydrolysis of cellulose. 
Due to the heterogeneity and complexity of hemicelluloses, an extensive number of hemicellulases, capable of hydrolyzing the backbone and the side groups of the hemicelluloses, is required [53]. Consequently, the mechanisms that are involved in the hydrolysis of hemicelluloses are not yet fully understood [61]. Besides cellulases and hemicellulases, there are also non-hydrolytic accessory proteins that have an important part in LCB degradation, such as lytic polysaccharide monooxygenases, carbohydrate-binding modules, and expansins or expansin-like proteins [64].

There are several factors that negatively affect enzymatic hydrolysis of LCB polysaccharides. Lignin linked to hemicelluloses constitutes a structural barrier to enzymes decreasing its accessibility to cellulose, furthermore, the higher cellulose crystallinity the lower surface area for enzyme attack. Enzymes can also unproductively bind to lignin. All of these factors stress the importance of LCB pretreatments [62]. The addition of surfactants, which bind to lignin instead of enzymes, increases the effectiveness of enzymatic hydrolysis, lowering the enzyme loading need, and consequently, the processing costs [53]. Moreover, formic acid, furfural, and lignin degradation products generated during pretreatments are inhibitory to both cellulases and hemicellulases [64,65]. Also, during enzymatic hydrolysis, thermal denaturation of enzymes might occur and, consequently extensive research focused on developing thermostable enzymes, which can function at temperatures of 60-100 ${ }^{\circ} \mathrm{C}$ [62]. CBH and BG are strongly inhibited by their reaction products, cellobiose, and glucose, respectively [61]. Similarly, xylose, xylan, and xylo-oligosaccharides can also inhibit enzymatic hydrolysis of LCB. Hence, soluble sugars, i.e., monomeric sugars and short oligosaccharides, arising from hydrolysis, can be viewed as inhibitory compounds [47].

Table 2 summarizes the main advantages and disadvantages of the three types of hydrolysis. Although enzymatic hydrolysis is slower than acidic hydrolysis, its mild reaction conditions make it the hydrolysis technique that is usually chosen for industrial applications [59].

Table 2. Hydrolysis agents, advantages and disadvantages of different types of hydrolysis.

\begin{tabular}{cccc}
\hline Hydrolysis & Concentrated Acid & Diluted Acid & Enzymatic \\
\hline Hydrolysis agent & $30-70 \% \mathrm{H}_{2} \mathrm{SO}_{4} / \mathrm{HCl}$ & $2-5 \% \mathrm{H}_{2} \mathrm{SO}_{4} / \mathrm{HCl}$ & $\begin{array}{c}\text { Cellulases and } \\
\text { hemicellulases }\end{array}$ \\
\hline Advantages & $\begin{array}{l}\text { Low temperature } \\
\text { High sugar yield }\end{array}$ & Low acid consumption & $\begin{array}{c}\text { Mild conditions } \\
\text { No inhibitors formation } \\
\text { High sugar yield }\end{array}$ \\
\hline Disadvantages & $\begin{array}{c}\text { Large amounts of acids } \\
\text { Equipment corrosion } \\
\text { Environmental and cost issues }\end{array}$ & $\begin{array}{c}\text { Hormation of inhibitors } \\
\text { Low sugar yield }\end{array}$ & $\begin{array}{c}\text { High cost } \\
\text { Slow reactions }\end{array}$ \\
\hline
\end{tabular}

\subsection{Fermentation}

The fermentable sugars coming from saccharification are the preferred substrate for bioethanol production by a diversity of microorganisms [66]. The anaerobic reaction of hexoses and pentoses conversion to ethanol can be expressed by Equations (1) and (2), respectively [67]:

$$
\begin{gathered}
\mathrm{C}_{6} \mathrm{H}_{12} \mathrm{O}_{6} \rightarrow 2 \mathrm{C}_{2} \mathrm{H}_{5} \mathrm{OH}+2 \mathrm{CO}_{2} \\
3 \mathrm{C}_{5} \mathrm{H}_{10} \mathrm{O}_{5} \rightarrow 5 \mathrm{C}_{2} \mathrm{H}_{5} \mathrm{OH}+5 \mathrm{CO}_{2}
\end{gathered}
$$

The maximum theoretical yield of the fermentation process is $0.511 \mathrm{~kg}$ of ethanol, produced with $0.489 \mathrm{~kg}$ of $\mathrm{CO}_{2}$, per $\mathrm{kg}$ of hexose or pentose [68].

\subsubsection{Fermentation Configuration}

Different possibilities to integrate hydrolysis and fermentation bioprocesses are possible. These configurations include separate hydrolysis and fermentation (SHF), simultaneous 
saccharification and fermentation (SSF), and consolidated bioprocessing (CBP) [69]. Figure 3 schematizes the possible configurations of bioethanol production from LCB.

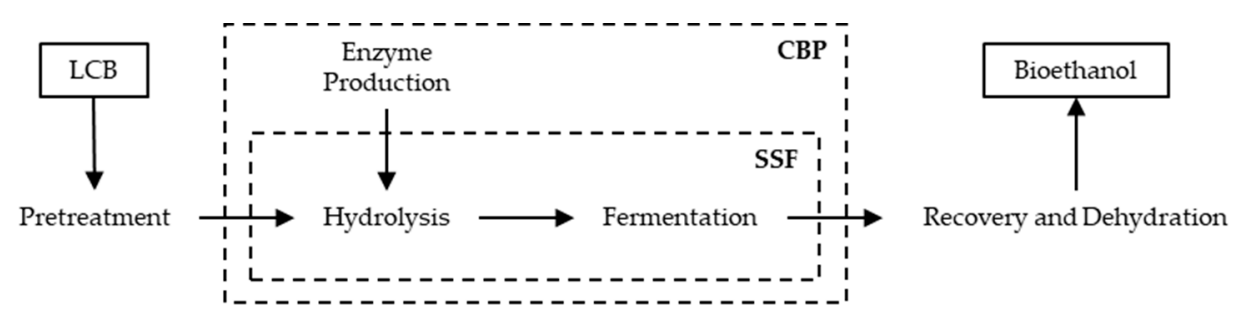

Figure 3. Possible configurations of the process for bioethanol production from LCB.

SHF consists of two consecutive steps: first, the enzymatic hydrolysis, followed by microbial fermentation. The main advantage of this configuration is that both processes can take place under their optimal conditions, which is very important due to the differences in optimal working temperatures of hydrolytic enzymes and ethanol producing microbial strains, usually about 50 and $28-37^{\circ} \mathrm{C}$, respectively. However, end-product inhibition of BG by its product glucose, during the first step is a major drawback of SHF [9,70]. End-product inhibition is eliminated in SSF, since hydrolysis and fermentation are performed simultaneously in the same vessel [71]. In this way, hydrolyzed sugars are immediately fermented into ethanol, improving both enzymatic hydrolysis efficiency and the ethanol yield. Another advantage of SSF configuration is the lower number of steps and reactors, which leads to lower costs $[72,73]$. The major disadvantage of SSF is the difference in optimum temperature required by hydrolytic enzymes and fermentative microorganisms. This can be overcome by lowering the temperature, despite occuring a reduction on cellulase hydrolytic efficiency [70]. Alternatively, the temperature could be increased, but, when exposed to temperatures higher than their optimal temperature, yeasts morphology and physiology changes and cell damage can occur, decreasing cell viability and yeast metabolism. Hence, high temperature leads to lower ethanol concentration, yield and productivity [70,72]. Several thermophilic/thermotolerant microorganisms belonging to species, like Clostridium, Thermoanaerobacterium, Thermoanaerobacter, and Kluyveromyces were identified as potential lignocellulosic ethanol producers for SSF configuration. However, these microorganisms still present several limitations, including low tolerance to ethanol, production of multiple by-products, and low ethanol yields and production rates [74,75].

In CBP, enzyme production, biomass hydrolysis, and fermentation occur in a single step. This configuration can result in a reduction of capital investment, since utilities that are associated with enzyme production are eliminated. Although there is a reduced operational complexity as the three processes occur in a single vessel, CBP requires the development of engineered microbial strains that are capable of producing hydrolytic enzymes, and, at the same time, showing an efficient ethanol production ability [72]. CBP strains modification can be centered in modifying cellulolytic microorganisms also in order to produce ethanol, or in gene modification of naturally ethanologenic microorganisms to produce cellulolytic enzymes [73]. Although the modification of bacteria, yeasts, and filamentous fungi for CBP through genetic and metabolic techniques has evolved in the past years, the development of microorganisms that can efficiently produce hydrolytic enzymes and ethanol is a major challenge. In fact, the microorganisms obtained are still not satisfactory, as they cannot produce high levels of ethanol without the addition of exogenous enzymes [76,77].

\subsubsection{Ethanologenic Microorganisms}

An ethanologenic microorganism should bear the following characteristics: (i) robust growth with simple requirements allowing for the use of inexpensive media; (ii) tolerance to acidic $\mathrm{pH}$ or high temperatures in order to retard contamination; (iii) high ethanol yield, above $90.0 \%$ of theoretical value; (iv) tolerance to ethanol concentration higher than $40.0 \mathrm{~g} \cdot \mathrm{L}^{-1}$; (v) ethanol productivity above $1.0 \mathrm{~g} \cdot \mathrm{L}^{-1} \cdot \mathrm{h}^{-1}$; and, (vi) resistance to inhibitors, being able to grow in undiluted hydrolysates [7]. 
Saccharomyces cerevisiae is the most commonly used microorganism for bioethanol production, being a robust and well-suited yeast for fermentation of lignocellulosic hydrolysates. S. cerevisiae has high ethanol yield, high ethanol and inhibitors tolerance, and can use a wide range of hexoses (glucose, mannose, and galactose) and disaccharides (sucrose and maltose) [14,44]. Among bacteria, Zymomonas mobilis, a gram-negative that is able to ferment glucose, sucrose, and fructose, is the most studied. When compared to S. cerevisiae, Z. mobilis has a higher ethanol yield and a much higher ethanol specific productivity, since it produces less biomass [73,78]. It also presents a higher ethanol tolerance. However, Z. mobilis is able to utilize a narrower range of sugars and has lower tolerance to inhibitors, like acetic acid [68]. Besides, Z. mobilis requires a neutral $\mathrm{pH}$ range, a common feature to most bacterial species $[75,79]$.

Although Z. mobilis and S. cerevisiae are the most commonly utilized microorganisms, they are incapable of fermenting pentoses [73]. Hydrolysates obtained from LCB present a high content in pentoses, mainly xylose, which can reach about $25 \%$ of sugars, followed by arabinose [59]. Scheffersomyces stipitis, Candida shehatae, and Pachysolan tannophilus are the most efficient yeasts to use pentoses, in addition to hexoses [69]. However, these yeasts require micro-aerophilic conditions and are sensitive to low $\mathrm{pH}$, inhibitors and high ethanol concentration. S. stipitis is the most promising pentose-fermenting organism for industrial applications, presenting the best performance in xylose fermentation with a higher ethanol yield $[73,80]$.

Besides yeasts and bacteria, filamentous fungi, such as Mucor indicus, Neurospora intermedia, Peniophora cinereal, and Trametes suaveolens, were also tested for ethanol production [81-83]. Some of these microorganisms are capable of fermenting both hexoses and pentoses [84-86], and since several of these microorganism have the ability of producing both lignocellulolytic enzymes and ethanol, they could be applied for CBP [87-89]. Nevertheless, low ethanol yields, due to the formation of significant amounts of by-products (e.g., acetic acid), low productivity and low growth rates are associated to ethanol production by filamentous fungi [87,90-92].

\subsection{Recovery and Dehydration}

Generally, at the end of the fermentative step, the broth contains only about $5 \mathrm{wt} \%$ of bioethanol, a low value when compared with first generation bioethanol, which can reach $12 \mathrm{wt} \%$. The fermentation broth is first distilled in a stripper column that concentrates ethanol to above $20 \mathrm{wt} \%$, and, then the ethanol stream is further concentrated in a rectifier column to no more than $95.6 \mathrm{wt} \%$ ethanol in water, due to the formation of a minimum boiling azeotrope at $78.15^{\circ} \mathrm{C}$ and $1 \mathrm{~atm}$. Distillation is energy-intensive, accounting for $60-80 \%$ of total separation cost of bioethanol from water, particularly due to low ethanol concentration in the broth. In order to be blended with gasoline, anhydrous ethanol (>99.5 wt \% ethanol) should be obtained and a dehydration step after distillation is required [93,94]. In the past, dehydration was usually achieved by azeotropic distillation [52]. Due to the high energy demand, azeotropic distillation was replaced by adsorption with zeolite molecular sieves [93].

\section{Bioethanol Production from Kraft Pulp}

Chemical pulping removes lignin and even targets hemicelluloses to some extent. Therefore, this process, which is primarily used for the manufacturing of paper and cellulose derivatives, can be considered as a pretreatment method of LCB [48]. The pulping process can be chemical, semi-chemical, or mechanical [39]. Chemical pulping alone represents about $77 \%$ of the virgin pulps produced globally [20]. Contrary to mechanical pulping, the goal of chemical pulping is delignification through lignin chemical degradation and solubilization. Although chemical pulping processes present the lowest yields, $45-60 \%$, pulps with better strength properties are obtained [39,95].

\subsection{Kraft Pulping}

Kraft pulping, which is also called sulfate process, corresponds to more than $95 \%$ of the chemical pulps produced [20] and consists on the reaction of an alkaline aqueous solution containing sodium 
hydroxide and sodium sulfide (i.e., white liquor) at high temperature $\left(150-170{ }^{\circ} \mathrm{C}\right)$ with lignin. When this solution contacts with wood chips, hydroxide and hydrosulfide anions react with lignin, which is partly degraded into phenolic fragments, whose dissolution removes almost $90 \%$ of the lignin from the wood. Kraft fibers have a very high mechanical quality and they can be obtained from any wood. However, Kraft cooking conditions lead to hemicelluloses and some cellulose loss as well as to a lower degree of polymerization of cellulose [41]. At the end of the process, besides Kraft pulp, black liquor is also obtained. The black liquor is firstly concentrated by evaporation and then burned in a recovery boiler, producing energy to fuel the pulp mill and allowing for the recovery of the chemicals used in the process. In this way, an almost closed system with minimal pollution is implemented [95].

A higher pulp yield is observed when applying the Kraft pulping process to hardwood, since xylan, which is more resistant to the Kraft pulping conditions, is the predominant hemicellulose in hardwoods. Hardwoods also present lower lignin content than softwoods, and softwood lignin contains more carbon-carbon bonds, which are not affected by the cooking conditions. Hence, lignin removal is easier with hardwood [41]. The many advantages of Kraft pulping also include low sugar degradation and pulps free of inhibitors, like furfural and HMF [23,96].

\subsection{Bioethanol Production}

Different studies already proved the viability of Kraft pulping as a LCB pretreatment by obtaining hydrolysates with sugar profiles suitable for fermentation through enzymatic hydrolysis of Kraft pulp of different origins, including sweet sorghum bagasse [97], pine, poplar, birch, beech, and wheat straw [96,98], hemp [98], eucalyptus [99], moso bamboo [100], spruce, and birch-aspen mixture [101]. Also, several studies focused on the fermentation configuration to produce ethanol from Kraft pulp. Additionally, the possibility of obtaining other products from Kraft pulp by applying simultaneous saccharification and fermentation was also assessed. These products included caffeic acid, a building block for thermoplastics and precursor for biologically active compounds [102], phenyllactic acid, a precursor for pharmaceutical and bio-based polymers [103], and D-lactic acid, a raw material for the synthesis of polylactic acid [104].

Table 3 summarizes the studies about bioethanol production from Kraft pulp found in the literature. Monrroy et al. (2012) investigated the SSF of Eucalyptus globulus Kraft pulps that were pretreated under different conditions. The ethanol concentrations varied between $30-38 \mathrm{~g} \cdot \mathrm{L}^{-1}$ and a maximum ethanol yield of $0.202 \mathrm{~g} \cdot(\mathrm{g} \mathrm{dw})^{-1}$ was obtained [23]. Ko et al. (2012) also studied SSF of unbleached Kraft pulps of E. globulus for ethanol production using a different S. cerevisiae strain and reported lower ethanol concentration and yield. Using unbleached Kraft pulps of Acacia confusa, the authors obtained an ethanol concentration of $5.88 \mathrm{~g} \cdot \mathrm{L}^{-1}$ and ethanol yield of $0.045 \mathrm{~g} \cdot(\mathrm{g} \mathrm{dw})^{-1}$. Alternatively, the authors applied acid steam-explosion as pretreatment for both woods, obtaining better results [105]. Buzała et al. (2017) tested the production of ethanol from Kraft pulps of different origins through SHF. Ethanol yield (per dry weight of wood) from the five hardwood unbleached pulps used ranged from $0.11-0.14 \mathrm{~g} \cdot(\mathrm{g} \mathrm{dw})^{-1}$. For the pine (i.e., softwood) unbleached and bleached pulps, ethanol yields of $0.02 \mathrm{~g} \cdot(\mathrm{g} \mathrm{dw})^{-1}$ and $0.20 \mathrm{~g} \cdot(\mathrm{g} \mathrm{dw})^{-1}$ were obtained, respectively. The low ethanol yield from the hydrolysate of unbleached pine pulp was attributed to the high content of extractives in the pulp [106]. Wistara et al. (2016) investigated the SSF of Kraft pulps of Jabon wood with different lignin content and freeness. Ethanol yield (per dry weight of pulp) varied between 0.022 and $0.129 \mathrm{~g} \cdot(\mathrm{g} \mathrm{dw})^{-1}$, and pulps with lower lignin contents and higher pulp freeness resulted in higher yields of ethanol [107].

Edgardo et al. (2008) isolated a thermotolerant S. cerevisiae strain and tested it for SSF of bleached Kraft pulp of Pinus radiata, obtaining a concentration of ethanol of $28 \mathrm{~g} \cdot \mathrm{L}^{-1}$ with an ethanol yield of $62 \%$. Alternatively, an organosolv pretreatment was applied, resulting in a lower amount of ethanol, $22 \mathrm{~g} \cdot \mathrm{L}^{-1}$, but with a higher yield of 73\% [108]. Bauer and Gibbons (2012) tested the SSF of Kraft pulp using different enzyme dosages for hydrolysis. Using S. cerevisiae, a maximum ethanol yield of $85.90 \pm$ $5.3 \%$ was achieved, with an ethanol concentration of $17.90 \pm 0.99 \mathrm{~g} \cdot \mathrm{L}^{-1}$ and a productivity of $0.25 \pm$ 
$0.015 \mathrm{~g} \cdot \mathrm{L}^{-1} \cdot \mathrm{h}^{-1}$. Similar results were obtained when Candida molischiana was used [109]. Amoah et al. (2017) investigated the production of bioethanol from hardwood unbleached Kraft pulp through CBP, obtaining lower values of ethanol concentration, productivity, and yield [110].

Table 3. Kraft pulp for bioethanol production.

\begin{tabular}{|c|c|c|c|c|c|c|}
\hline Feedstock & Config & Microorganism & $\begin{array}{l}{[\mathrm{EtOH}]} \\
\left(\mathrm{g} \cdot \mathrm{L}^{-1}\right)\end{array}$ & $\begin{array}{c}\operatorname{Prod}_{\mathrm{vol}} \\
\left(\mathrm{g} \cdot \mathrm{L}^{-1} \cdot \mathrm{h}^{-1}\right)\end{array}$ & $\begin{array}{c}\mathrm{Y}_{\text {ethanol }} \\
\left(\mathrm{g} \mathrm{g} \mathrm{dw}^{-1}\right)\end{array}$ & Ref. \\
\hline E. globulus & SSF & S. cerevisiae IR2T9 a & $30-38$ & NA & $0.168-0.202^{b}$ & [23] \\
\hline E. globulus & \multirow{2}{*}{ SSF } & \multirow{2}{*}{ S. cerevisiae D5A } & 5.67 & 0.033 & $0.042^{b}$ & \multirow{2}{*}{ [105] } \\
\hline A. confusa & & & 5.88 & 0.035 & $0.045^{\mathrm{b}}$ & \\
\hline Populus trichocarpa & \multirow{7}{*}{ SHF } & \multirow{7}{*}{ S. cerevisiae wild-type } & NA & NA & $0.12^{b}$ & \multirow{7}{*}{ [106] } \\
\hline Populus maximowiczi & & & NA & NA & $0.11^{\mathrm{b}}$ & \\
\hline Populus tremula & & & NA & NA & $0.14^{\mathrm{b}}$ & \\
\hline Betula pendula & & & NA & NA & $0.13^{b}$ & \\
\hline Fagus sylvatica & & & NA & NA & $0.13^{b}$ & \\
\hline Pinus sylvestrii & & & NA & NA & $0.02^{b}$ & \\
\hline Pinus sylvestrii ${ }^{\mathrm{b}}$ & & & NA & NA & $0.20^{\mathrm{b}}$ & \\
\hline Jabon wood & SSF & & NA & NA & $0.022-0.129^{c}$ & [107] \\
\hline Feedstock & Config & Microorganism & $\begin{array}{l}{[\mathrm{EtOH}]} \\
\left(\mathrm{g} \cdot \mathrm{L}^{-1}\right)\end{array}$ & $\begin{array}{c}\text { Prod }_{\text {vol }} \\
\left(\mathrm{g} \cdot \mathrm{L}^{-1} \cdot \mathrm{h}^{-1}\right)\end{array}$ & $\begin{array}{c}\mathrm{Y}_{\text {ethanol }} \\
\text { (\% theoret.) }\end{array}$ & Ref. \\
\hline Pinus radiata $\mathrm{d}$ & SSF & S. cerevisiae IR2-9a a & 28 & 0.388 & 62 & [108] \\
\hline \multirow{2}{*}{ NS } & \multirow{2}{*}{ SSF } & S. cerevisiae NRRL Y-2034 & $14.24-17.90$ & $0.15-0.25$ & $68.33-85.90$ & \multirow{2}{*}{ [109] } \\
\hline & & C. molischiana ATCC 2516 & $12.51-18.21$ & $0.19-0.24$ & $60.00-87.38$ & \\
\hline NS & CBP & S. cerevisiae MT8-1 ${ }^{\mathrm{e}}$ & 0.71 & 0.010 & 41.2 & [110] \\
\hline
\end{tabular}

$[\mathrm{EtOH}]$ ethanol concentration; Prod $_{\mathrm{vol}}$ ethanol volumetric productivity; $\mathrm{Y}_{\text {ethanol }}$ ethanol yield; NA not available; NS not specified; ${ }^{a}$ thermal acclimatized; ${ }^{b}$ per dry weight of wood; ${ }^{c}$ per dry weight of pulp; ${ }^{d}$ bleached Kraft pulp; ${ }^{e}$ transformed to express five cellulase genes.

\section{Bioethanol Production from Spent Sulfite Liquor}

\subsection{Sulfite Pulping}

Sulfite pulping is the second most used pulp producing process, after Kraft pulping, with around 2.2 million tonnes of sulfite pulp annually produced [20]. There are different types of sulfite pulping, based on the $\mathrm{pH}$ range of the resultant cooking liquor: acid bisulfite $(\mathrm{pH} 1-2)$, bisulfite $(\mathrm{pH} 3-5)$, neutral sulfite ( $\mathrm{pH}$ 6-9), and alkaline sulfite ( $\mathrm{pH} 10-13.5)$. The temperature of the process ranges from 130 to $180^{\circ} \mathrm{C}$. Sulfur dioxide $\left(\mathrm{SO}_{2}\right)$ is the basic pulping reagent that is used with different pulping bases, namely $\mathrm{Na}^{+}, \mathrm{Ca}^{2+}, \mathrm{Mg}^{2+}$, or $\mathrm{NH}_{4}{ }^{+}$. Currently, magnesium is the most commonly base used for the sulfite process. When using $\mathrm{Mg}_{2}{ }^{+}$, both acid bisulfite and bisulfite pulping can be carried out, since the aqueous magnesium bisulfite solutions are soluble in a $\mathrm{pH}$ range up to $6[39,111]$. The advantage of magnesium bisulfite process is that, as in Kraft pulping, $\mathrm{MgO}$ and $\mathrm{SO}_{2}$ can be recovered from the spent sulfite liquor (SSL) that was obtained at the end of the process by combustion after previous evaporation. Unlike the Kraft process, not all wood species are suitable for sulfite pulping. This process can only be applied to softwoods like spruce, fir, and hemlock, and hardwoods, like beech, eucalyptus, poplar, and birch. Woods like pine, larch, and Douglas fir are not suitable for sulfite pulping due condensation reactions of the phenolic compounds in the heartwood with lignin in acidic conditions, releasing products that cannot be dissolved [95].

During the sulfite pulping process, lignin is degraded by sulfonation and hydrolysis reactions to water-soluble lignosulfonates (LS). Degradation of wood polysaccharides by hydrolysis also occurs, yielding hexoses and pentoses sugars that are present in the SSL, besides lignin [38]. Under acidic pulping conditions, hemicelluloses are essentially hydrolyzed and faster than cellulose. In fact, there is lower cellulose degradation during acidic sulfite pulping than in the Kraft process. Conversely to glucuronoxylans, i.e., the main hemicelluloses in hardwood, galactoglucomannan, present mainly in 
softwood, show a better retention in pulp during acid sulfite than during Kraft pulping. Acid-catalyzed dehydration ultimately leads to the formation of furfural from pentoses and HMF from hexoses, which can be later converted into levulinic and formic acids [39,111].

\subsection{Bioethanol Production}

Concerning bioethanol production, the most interesting feedstock coming from sulfite pulping is the liquor, SSL, a side product that is obtained at end of the process. The main components of SSL are LS and carbohydrates resulting from hemicelluloses, being mostly fermentable sugars, such as arabinose, xylose, mannose, galactose, and glucose. SSL also contains sugar degradation products, like furfural and HMF, besides acetic acid, uronic acids, methyl glyoxal, formaldehyde, methyl alcohol, and extractives [112]. Regarding the black liquor from Kraft pulping, it is unsuitable for bioethanol production since it contains no sugars but mainly lignin and carbohydrate degradation products (i.e., hydroxycarboxylic acids, acetic acid, and formic acid), and also contains small amounts of extractives (e.g., turpentine and talloil) and other miscellaneous products [25,38,112].

Due to the differences between softwood and hardwood hemicelluloses, the sugar composition of SSL depends on the type of wood that is used for pulping. SSLs resulting from pulping of softwood (softwood spent sulfite liquor-SSSL) contain mainly hexoses, while SSLs obtained from pulping of hardwood (hardwood spent sulfite liquor-HSSL) present a higher proportion of pentoses [25]. Furthermore, SSL is a low cost and abundant feedstock with a production estimated in 2015 of 90 billion liters per year $[39,113]$. SSL also has a high biological oxygen demand, presenting a disposal problem that can be solved by using it for the production of added-value products [114] that include bioethanol, xylitol [115,116], polyhydroxyalkanoates [117,118], organic acids [119], and fumaric acid [120].

Ethanol production from SSLs has been studied for a long time, with several articles about this topic published in the 80s [121-125] and in the 90s [126-131]. Table 4 summarizes the most recent studies using SSL from different origins for bioethanol production. Portugal-Nunes et al. (2015) studied the effect of cell immobilization and $\mathrm{pH}$ on S. stipitis fermentation of bio-detoxified SSL of E. globulus (hardwood). The simultaneous application of cell immobilization and $\mathrm{pH}$ control at 5.5 favored the fermentative metabolism, leading to an improvement of 1.3-fold on the ethanol yield and maintaining the volumetric productivity [113]. Harner et al. (2015) used genome shuffling to obtain Pachysolen tannophilus mutants with higher tolerance to inhibitors in HSSL. Among the genome shuffled strains, GHW301 produced the highest amount of ethanol, $7.4-8.5 \mathrm{~g} \cdot \mathrm{L}^{-1} \cdot \mathrm{h}^{-1}$, in the different media containing HSSL (70-100\% v/v) [132]. Pereira et al. (2015), using an evolutionary engineering strategy, obtained a population of S. stipitis with increased tolerance to E. globulus SSL inhibitors. Several isolates adapted to HSSL inhibitors were obtained and the most efficient isolate was used for the fermentation of undetoxified HSSL, resulting in an improved performance when compared to the parental strain [133]. The same isolate provided better results using a two-stage aeration fermentation strategy [50]. Takahashi et al. (2015) studied the use of anion exchange resins to remove acetic acid from HSSL. These authors showed that a $\mathrm{CaO}$ treatment followed by neutralization with $\mathrm{CO}_{2}$ and a two-stage strong base ion exchange column removed about $90 \%$ of the acetic acid. The fermentation of the detoxified HSSL presented better results than the untreated HSSL, yielding $10.6 \mathrm{~g} \cdot \mathrm{L}^{-1}$ of ethanol with a productivity of $0.441 \mathrm{~g} \cdot \mathrm{L}^{-1} \cdot \mathrm{h}^{-1}$ [134]. Pereira et al. (2012) reported that the fermentation of E. globulus SSL, bio-detoxified with fungus Paecilomyces variotii, by $S$. stipitis resulted in a maximum ethanol concentration of $2.4 \mathrm{~g} \cdot \mathrm{L}^{-1}$, corresponding to an ethanol yield of $0.24 \mathrm{~g} \cdot \mathrm{g}^{-1}$ [135]. Pinel et al. (2011) used genome shuffling to obtain $S$. cerevisiae mutants with a higher tolerance to inhibitors in HSSL. The genome shuffled strain R57 was the most productive, achieving ethanol yields of $80 \%$ of the theoretical [136]. Bajwa et al. (2010) also applied genome shuffling to improve tolerance to HSSL inhibitors. Two S. stipitis mutant strains were tested for ethanol fermentation of undiluted HSSL, producing about $1.8 \mathrm{~g} \cdot \mathrm{L}^{-1}$ of ethanol [137]. Xavier et al. (2010) studied the deacidification of SSL of E. globulus using S. cerevisiae and the subsequent fermentation of the obtained HSSL. Ethanol production was ineffective probably due to the presence of polyphenolic inhibitors. The authors then tested the 
ion-exchange resins for the detoxification of the SSL of E. globulus. The fermentation of the detoxified HSSL resulted in $8.1 \mathrm{~g} \cdot \mathrm{L}^{-1}$ of ethanol, with an ethanol yield of $0.49 \mathrm{~g} \cdot \mathrm{g}^{-1}$ [138]. Nigam (2001) and Bajwa et al. (2009) also studied the fermentation of HSSL using S. stipitis [114,139].

Table 4. Spent sulfite liquor for bioethanol production.

\begin{tabular}{|c|c|c|c|c|c|c|}
\hline Feedstock & Detox. & Microrganism & $\begin{array}{l}{[\mathrm{EtOH}]} \\
\left(\mathrm{g} \cdot \mathrm{L}^{-1}\right)\end{array}$ & $\underset{\left(\mathrm{g} \cdot \mathrm{L}^{-1} \cdot \mathrm{h}^{-1}\right)}{\operatorname{Prod}_{\mathrm{vol}}}$ & $\begin{array}{l}Y_{\text {ethanol }} \\
\left(\mathrm{g} \cdot \mathrm{g}^{-1}\right)\end{array}$ & Ref. \\
\hline \multicolumn{7}{|c|}{ Hardwood } \\
\hline E. globulus & Biological a $^{\text {a }}$ & S. stipitis NRRL-7124 b & NA & $0.028 \pm 0.005$ & $0.26 \pm 0.06$ & [113] \\
\hline NS & No & P. tannophilus GHW301 ${ }^{\mathrm{c}}$ & $7.4-8.5$ & NA & NA & [132] \\
\hline & & S. stipitis NRRL-7124 & 1.76 & 0.02 & 0.13 & \\
\hline E. globulus & No & S. stipitis $\mathrm{C}_{4}$ isolate ${ }^{\mathrm{d}}$ & 4.60 & 0.05 & 0.16 & [133] \\
\hline E. globulus & No & S. stipitis $\mathrm{C}_{4}$ isolate $\mathrm{d}^{\mathrm{d}}$ & 12.2 & 0.04 & 0.39 & [50] \\
\hline NS & $\begin{array}{l}\mathrm{CaO}+\text { Anion } \\
\text { exchange }\end{array}$ & S. stipitis CBS6054 & 10.6 & 0.441 & NA & [134] \\
\hline E. globulus & Biological ${ }^{\mathrm{a}}$ & S. stipitis NRRL-7124 & 2.4 & 0.086 & 0.24 & [135] \\
\hline NS & No & S. cerevisiae $\mathrm{R} 57^{\mathrm{C}}$ & NA & NA & 0.41 & [136] \\
\hline NS & No & S. stipitis GS301 ${ }^{\mathrm{c}}$ and GS302 ${ }^{\mathrm{c}}$ & 1.8 & NA & NA & [137] \\
\hline E. globulus & Ion exchange & S. stipitis NRRL-7124 & 8.1 & 1.22 & 0.49 & [138] \\
\hline \multicolumn{7}{|c|}{ Softwood } \\
\hline Snruce & & S. cerevisiae Thermosacc ${ }^{\mathrm{e}}$ & 9 & 0.41 & 0.25 & \\
\hline Spruce & No & S. cerevisiae CCUG $53310^{\mathrm{f}}$ & 11 & 0.5 & 0.31 & [140] \\
\hline NS & No & S. cerevisiae Red Star & NA & $0.00-0.19$ & NA & [141] \\
\hline NS & $\begin{array}{l}\mathrm{CaO}+\mathrm{Ion} \\
\text { exchange }\end{array}$ & S. stipitis CBS6054 & 1.3 & 0.054 & NA & [142] \\
\hline NS & No & S. cerevisiae CCUG $53310^{\mathrm{f}}$ & $10.05 \pm 0.09$ & $0.838 \pm 0.008$ & NA & [143] \\
\hline \multicolumn{7}{|c|}{ Hardwood + Softwood } \\
\hline Spruce + Beech & No & S. cerevisiae IBB10B05 g & NA & NA & $0.31-0.44$ & [144] \\
\hline
\end{tabular}

Johansson et al. (2014) studied the production of ethanol from SSL of spruce (softwood) by two different S. cerevisiae strains. S. cerevisiae CCUG 53,310 resulted in a better ethanol production from SSSL, since it was adapted to the sulfite mill conditions [140]. Guo and Olsson (2014) investigated the ethanol production from four different SSSL side streams $25 \%$ concentrated by S. cerevisiae. One of the side streams was unfermentable, while for the other three streams, the volumetric productivity varied between 0.04 and $0.19 \mathrm{~g} \cdot \mathrm{L}^{-1} \cdot \mathrm{h}^{-1}$. The authors also tested different detoxification methods, reporting that over-liming was the most efficient one resulting in better fermentability of the streams tested [141]. Tanifuji et al. (2013) studied ethanol production from SSSL that was treated with combined $\mathrm{CaO}$ and ion exchange resin by S. stipitis. The authors reported that the detoxification method removed most acetic acid and all sulfite ion present in the SSSL and that the fermentation resulted in a maximum ethanol concentration of $1.3 \mathrm{~g} \cdot \mathrm{L}^{-1}$ at $24 \mathrm{~h}$ of fermentation. All monosaccharides were consumed after $16 \mathrm{~h}$, and additionally some oligosaccharides were also consumed [142]. Johansson et al. (2011) examined the influence of cultivation procedure and the amount of yeast pitched on the fermentation of SSSL by S. cerevisiae. The authors concluded that cultivating the yeast in the same substrate as the subsequent fermentation resulted in a higher ethanol concentration and that increased inoculum size leads to better ethanol productivity. When $0.8 \mathrm{~g} \cdot \mathrm{L}^{-1}$ of cells previously cultivated in SSSL were used as inoculum, an ethanol concentration of $10.05 \pm 0.09 \mathrm{~g} \cdot \mathrm{L}^{-1}$ was obtained [143]. Novy et al. (2013) used a xylose-fermenting $S$. cerevisiae for the co-fermentation of hexose and pentose sugars of SSL obtained from a mixture of spruce $(80 \%)$ and beech $(20 \%)$. The authors tested the addition of different media supplements to the SSL, reporting ethanol yields varying from 0.31 and $0.44 \mathrm{~g} \cdot \mathrm{g}^{-1}$ [144]. Some authors have compared the fermentation of hardwood and softwood SSLs [145-147]. More than 50\% of the SSLs produced every year are HSSLs, however, the production of bioethanol from HSSL still 
faces some challenges [25]. Contrary to the SSSLs, which have been used for ethanol production for centuries, HSSLs present a high amount of pentose sugars, namely xylose, in its composition [148]. Hence, S. stipitis, a hexose and pentose-fermenting yeast, has been studied for ethanol production from HSSL (Table 5). However, this yeast requires microaerophilic conditions for optimal ethanol production, which still need to be optimized. S. stipitis is also highly sensitive to the inhibitors found in HSSLs, such as formic, acetic and levulinic acids, phenolics, and furfural [25]. The techniques that have already studied to alleviate this inhibitory effect can be divided in two groups: one based on the removal of inhibitory compounds using different detoxification methods (e.g., biological [113,135], ion exchange $[134,138,149])$ and the other based on the increasing the tolerance of microorganisms to the inhibitors (e.g., by UV mutagenesis and genome shuffling [137], by adaptation to the HSSL [113,133]).

The aforementioned inhibitors are also present in SSSL [141]. Hence, fermentation of SSSL with $S$. cerevisiae originated from SSL ethanol plant and its adaption to this medium was also studied $[140,143]$.

\section{Bioethanol Production from Pulp and Paper Sludge}

\subsection{Pulp and Paper Mill Sludge}

The production of pulp and paper involves a great amount of water for the reaction media and as wash water. The effluent generated must be treated and most pulp and paper mills treat their own wastewater. Hence, besides rejects, like bark, branches, shives, and fine chips and spent sulfite or black liquors, the main organic waste resulting from the wastewater treatments is pulp and paper mill sludge (PPMS), which is also the largest waste stream generated in terms of volume presenting a low dry solid content $[150,151]$. Up to one metric ton of wet PPMS can be formed per ton of paper produced, due to the high quantity of water processed [26]. There is a great variability in PPMS properties, such as organic content, ash content, $\mathrm{pH}$, and heating value. These properties depend on the type of raw material and input, the papermaking process and wastewater cleaning technique [151,152]. Also, the chemical composition of the PPMS produced in different pulp mills has a large variation. Boshoff et al. (2016) verified this variability in the chemical composition of 37 PPMSs that were collected from different pulp and paper mills. This variability depends on the mill feed and the upstream processing [153]. Wood and cellulose fibers of different lengths, lignin, and organic binders are the main organic components of PPMS, while the inorganic components usually present are paper additives, like clay and calcium carbonate and heavy metals, which originate from the wood [154].

There are three major PPMS types: primary sludge, secondary sludge, and de-inking sludge. Primary sludge is generated in the primary wastewater treatment, which consists mainly of physicochemical processes, like sedimentation and flotation [151]. Generally, primary sludge is the main mill-generated PPMS and is rich in cellulose fibers, being also composed by clay, ash, fillers, and other inorganic material. Secondary sludge, also known as biosludge or waste activated sludge, is generated during aerobic wastewater treatment, having a primarily organic composition and presents a high microbial content $[152,155]$. De-inking sludge is the residue that is produced in the paper recycling process and is composed by short fibers, ink and dyes, de-inking agents, adhesives, kaolin, clay, calcium carbonate, heavy metals, and minerals [151]. The PPMS should be thickened and dewatered and it is usually landfilled or incinerated for combined heat and power generation. Landfilling presents some problems, including the large volumes of sludge and the leaking of hazardous substances into the environment. This practice is decreasing due to restrictions in legislation and increased taxes. Besides land application, other alternative management practices for PPMS include integration in materials, like biocomposites of wood and plastic, cement, asphalt, and adsorbent-absorbent [151]. Although incineration reduces the volume of material to be landfilled, the dewatering step can yield a negative energy balance and the incinerator air emissions should be limited [156]. 


\subsection{Bioethanol Production}

Several products were already obtained from PPMS: bioethanol [26,157], butanol through acetone-butanol-ethanol fermentation [158,159], hydrogen [160], cellulase [160,161], biogas from anaerobic digestion (AD) [162,163], and bio-oil from pyrolysis [164,165].

Using PPMS for bioethanol production represents different economic benefits, starting by zero-purchasing cost, or even a negative cost, since using PPMS to produce other products significantly reduces the disposal costs. Additionally, as PPMS results from extensive processing of the pulp and paper production processes, it contains short extension fibers that are easily hydrolyzed by enzymes into fermentable sugars, and the lignin content is low. Consequently, PPMS requires no pretreatment for the production of ethanol and inhibitors resulting from lignin can be neglected $[159,166]$. The major challenge of using PPMS for bioethanol production is the high content in ash, namely $\mathrm{CaCO}_{3}$, which adsorbs to the enzymes and increases de $\mathrm{pH}$ of the sludge, hindering enzymatic hydrolysis. In order to surpass this limitation, acidic treatments are frequently used to neutralize $\mathrm{CaCO}_{3}$ [161,167-169]. Moreover, the high ash content limits solid loading, leading to bigger reaction vessels, and, consequently, to increased costs. PPMS also presents a high-water holding capacity and viscosity, which results in inadequate mixing and mass transfer. Fed-batch fermentations were tested as a strategy to overcome these challenges $[153,157]$.

Table 5. Pulp and paper mill sludge for bioethanol production.

\begin{tabular}{|c|c|c|c|c|c|c|}
\hline Type of PPMS & Fermentation & Microorganism & $\begin{array}{l}{[\mathrm{EtOH}]} \\
\left(\mathrm{g} \cdot \mathrm{L}^{-1}\right)\end{array}$ & $\underset{\left(\mathrm{g} \cdot \mathrm{L}^{-1} \cdot \mathrm{h}^{-1}\right)}{\operatorname{Prod}_{\mathrm{vo}}}$ & $Y_{\text {ethanol }}(\%)$ & Ref. \\
\hline $\begin{array}{l}\text { Recycled paper } \\
\text { sludge }\end{array}$ & Batch/SHF & S. cerevisiae PE-2 & $5.6-6.3$ & $0.47-0.52$ & $67.9-76.8$ & [26] \\
\hline \multirow{4}{*}{ Primary sludge } & \multirow{2}{*}{ Batch/SSF } & S. cerevisiae & 22.7 & 0.94 & 80.6 & \multirow{4}{*}{ [157] } \\
\hline & & K. marxianus NCYC 1426 & 20.7 & 0.86 & 73.7 & \\
\hline & \multirow[t]{2}{*}{ Fed-batch/SSF } & $\begin{array}{c}\text { S. cerevisiae } \\
\text { (baker yeast) }\end{array}$ & 40.7 & 0.52 & 32.4 & \\
\hline & & K. marxianus NCYC 1426 & 24.2 & 0.31 & 18.8 & \\
\hline Virgin pulp sludge & \multirow[b]{2}{*}{ Fed-batch/SSF } & \multirow[b]{2}{*}{ S. cerevisiae MH1000 } & 34.2 & 0.230 & 66.9 & \multirow[b]{2}{*}{ [153] } \\
\hline $\begin{array}{l}\text { Corrugated recycled } \\
\text { paper sludge }\end{array}$ & & & 45.5 & 0.448 & 78.2 & \\
\hline \multirow{2}{*}{ Primary sludge } & Batch/SSF & \multirow{2}{*}{ S.cerevisiae ATCC 26602} & $41.7-41.9$ & $0.78-0.80$ & $48.9-49.4$ & \multirow{2}{*}{ [170] } \\
\hline & Fed-batch/SSF & & $33.3-39.7$ & $0.43-0.52$ & $39.1-46.4$ & \\
\hline Primary sludge ${ }^{a}$ & Batch/SHF & FermPro $^{\mathrm{TM}}$ & $25-30$ & $1.73-3.28$ & $94.5-95.7$ & [167] \\
\hline \multirow[t]{2}{*}{ Primary sludge ${ }^{b}$} & \multirow[t]{2}{*}{ Batch/SHF } & $\begin{array}{l}\text { S. cerevisiae } \\
\text { (baker yeast) }\end{array}$ & 8.3 & 0.16 & 64.7 & \multirow[t]{2}{*}[168]{} \\
\hline & & P. stipitis DSM 3651 & 10.5 & 0.20 & 76.5 & \\
\hline \multirow[t]{2}{*}{ Primary sludge $^{c}$} & \multirow{2}{*}{ Batch/SHF } & $\begin{array}{c}\text { S. cerevisiae } \\
\text { (baker yeast) }\end{array}$ & 7.1 & 0.14 & 0.32 & \multirow[t]{2}{*}[168]{} \\
\hline & & P. stipitis DSM 3651 & 8.5 & 0.16 & 62.7 & \\
\hline Primary sludge & Batch/SHF & S. cerevisiae GIM-2 & 9.5 & 0.59 & 66.5 & [171] \\
\hline
\end{tabular}

$[\mathrm{EtOH}]$ ethanol concentration; Prod $_{\mathrm{vol}}$ ethanol volumetric productivity; $\mathrm{Y}_{\mathrm{ethanol}}$ ethanol yield; NA not available; NS not specified; ${ }^{a}$ addition of cationic polyacrylamide accelerant XP10020 during enzymatic hydrolysis; ${ }^{\mathrm{b}} \mathrm{HCl}$ treated; ${ }^{c}$ spent acid treated.

Table 5 shows different studies of bioethanol production from pulp and paper mill sludge. Schroeder et al. (2017) investigated the production of ethanol from recycled paper sludge. When applying SHF configuration, these authors reported that the nutritional supplementation of the hydrolyzed sludge resulted in higher ethanol concentration and yield, but it was not essential to achieve good results. SSF without supplementation resulted in higher global yield and ethanol production in a shorter time period than SHF. Additionally, it was concluded that hydrolysis was the rate-limiting step in both configurations, most likely due to the interference of the high ash and solid 
contents, since no neutralization of the sludge was performed [26]. Mendes et al. (2017) studied the production of ethanol from primary sludge using SSF. In batch fermentation assays with a carbohydrate content of $50 \mathrm{~g} \cdot \mathrm{L}^{-1}$, S. cerevisiae led to better results than the thermotolerant Kluyveromyces marxianus. Fed-batch mode allowed for a higher solid loading and a lower enzymatic load, providing a higher amount of ethanol produced but with lower ethanol yields [157]. Boshoff et al. (2016) studied fed-batch SSF of two different PPMS, reporting that sludge from virgin pulp production presented high viscosity, and therefore provided lower ethanol concentration and yield than sludge from corrugated recycled paper. These authors also concluded that digestibility, water holding capacity, and viscosity were the major factors affecting this high solid loading fed-batch SSF [153].

Mendes et al. (2016) tested batch and fed-batch SSF of two primary sludges. Batch fermentation of both sludges resulted in similar ethanol concentrations. For the same total effective enzyme dosage, fed-batch results were lower than those that were obtained in batch assays. Also, the sludge with higher ash content led to better fermentation results [170]. Gurram et al. (2015) tested chemical, with $\mathrm{HCl}$, and mechanical de-ashing of primary sludge, and found that the enzymatic hydrolysis performance improved in de-ashed sludges. The authors also investigated batch SHF of different primary sludges, either chemically de-ashed or without de-ashing, when two different accelerants or $\mathrm{H}_{2} \mathrm{O}_{2}$ pretreatment were applied to enzymatic hydrolysis. For the four sludges tested, the addition of cationic polyacrylamide accelerant XP10020 during enzymatic hydrolysis resulted in higher ethanol yield and productivity [167]. Mendes et al. (2014) studied different inorganic and organic acids for the neutralization of $\mathrm{CaCO}_{3}$ in primary sludge, concluding that $\mathrm{HCl}$ or spent acid were efficient, but released $\mathrm{CO}_{2}$. The treated sludges were then enzymatically hydrolyzed, and the hydrolysate obtained was subsequently fermented. These authors compared hexose-fermenting yeast $S$. cerevisiae and the hexose and pentose fermenting yeast $S$. stipitis for ethanol production, since sludges resulting from pulp and paper mills processing of hardwoods contain a mixture of glucose and xylose, being S. stipitis that showed the better performance [168]. Peng and Chen (2011) studied batch SHF of primary sludge without any pretreatment. They used an optimized strategy based on statistical experimental design experiments to improve enzymatic hydrolysis performance and to get a successful subsequent fermentation by S. cerevisiae [171].

\section{Converting Pulp and Paper Mills into Biorefineries}

The forest-based sector that uses and generates LCB feedstocks can play a key role in the future bioeconomy [172]. The conversion of pulp and paper mills into biorefineries by the integrating of ethanol production could valorize the wastes resulting from the mills and diversifying the products, as well as increasing the profitability of pulp and paper industry.

One example of this conversion is the reorientation of closed Kraft pulp mills to bioethanol production $[23,24]$. Wu et al. (2014) evaluated the techno-economic potential of repurposing a Kraft mill for bioethanol production from loblolly pine [173]. Fornell et al. (2012) discussed the energy efficiency and performed an economic analysis of a conceptual Kraft pulp mill that was converted into a lignocellulosic ethanol plant $[174,175]$.

Although sulfite pulps correspond to less than $2 \%$ of the wood pulps produced annually [20] and a decrease in the number of sulfite mills is occurring, this process is attracting attention within the biorefinery concept, which could increase the profit of the existing mills [39]. Several authors already proposed the conversion of sulfite mills into integrated biorefineries. Rueda et al. (2016) performed a techno-economic assessment of different biorefinery approaches for the valorization of spent sulfite liquor. Of the three options assessed (i.e., furfural, xylitol, and ethanol), xylitol proved to be the best valorization option [116]. This study is based on their previous work, Rueda et al. (2015), in which several valorization options, including the production of lignosulfonates, xylitol, ethanol, polyhydroxybutyrate, polybutylene-succinate, furfural, and hydrogen were suggested based on the composition of SSL [115]. 
Petersen et al. (2016) considered different ways to produce energy and reduce emissions in a sulfite pulping mill, namely through the production of ethanol from SSL, combined with the production of methanol or Fischer-Tropsch crude from the bark residues resulting from wood processing. After determining contributions from the combined process to the economic and environmental performance, authors concluded that, at least in low scale, the integrating facility could be profitable [176]. Previously, Petersen et al. (2014) already performed a techno-economic analysis of the integration of bioethanol production from SSL in order to reduce the GHG emissions of sulfite pulping mills. The options for generating thermal and electrical energy from onsite bio-wastes were also included in the analysis [177].

The process for bioethanol production from PPMS could also be implemented in the existing pulp and paper mills, contributing to convert these industrial plants into integrated biorefineries. This integration can maximize the use of wood, reduce the operational costs, and increase the number of products, leading to increased revenue of the pulp and paper industry. Additionally, the use of PPMS as a biorefinery feedstock would decrease the amount of this waste requiring treatment, fitting well in the circular economy model, besides the environmental advantages [152,170]. Several authors have worked on this possibility. Fan and Lynd (2007) studied the process design and economics for the conversion of paper sludge to ethanol in a Kraft pulping mill. These authors considered that PPMS conversion to ethanol is a well-suited and low cost opportunity, given the negative feedstock cost, the small-scale and simple process, and since no pretreatment is required and the already existing infrastructure can be used [178]. Aksoy et al. (2011) analyzed four biorefinery technologies in Alabama for feedstock allocation, facility location, economic feasibility, and economic impacts. According to these authors, SSF of paper sludge for ethanol production was an economically feasible biorefinery technology with an over 80\% rate of return [179]. Machani et al. (2014) evaluated the technical and economic potential of integrating bioenergy production within pulp and paper mills, concluding that investing in ethanol production would be financially advantageous for the Quebec pulp and paper mill sector [180].

Since ethanol production from PPMS still faces the problems of low solid content and high $\mathrm{pH}$, Wang et al. (2014) proposed a design that combines paper sludge and rice straw to produce ethanol through the co-fermentation of hexoses and pentoses, and showed the potential of its economic viability [181]. Chen et al. (2014) performed an economic evaluation of the production of ethanol from different paper sludges, either fractionated to remove ash or non-fractionated. Financial and risk analysis indicated that fractionated virgin sludge to ethanol was the most profitable and presented a higher probability of success [182]. The study by Robus et al. (2016) presents the technical feasibility and economic viability of the expansion of paper mills to bioethanol production from paper sludge in the South African paper mills scenario. They demonstrated the economic viability of the production of bioethanol from paper sludge to substitute liquid petroleum gas that was used to generate heat for tissue paper drying on the paper machine [183]. Sebastião et al. (2016) evaluated the environmental performance of ethanol production from PPMS, using a cradle-to-gate life cycle assessment approach. These authors reported that the use of less $\mathrm{HCl}$ for neutralization and co-fermentation of xylose and glucose could improve the environmental impact, since enzymatic hydrolysis and neutralization of the $\mathrm{CaCO}_{3}$ were the main contributions to the environmental impact of the process [184]. Faubert et al. (2016) reviewed several PPMS management practices and the GHG generation associated, and conclude that, for ethanol production, there is a lack of information about determinants of GHG emissions and future research should focus on this topic [151].

High technical risk and high capital investment are two of the major weaknesses of industrial-scale bioethanol production from LCB. Kraft mills are well-established and their equipment and technologies, which has been commercially recognized for decades, including the wood preparation and the pulping process, can be used for the pretreatment of LCB [23,24]. Hence, the application of processes that are specifically developed for pulp and paper industry to bioethanol production in an integrated 
biorefinery seems like a promising solution for the aforementioned bottlenecks, increasing the opportunity of success of the ethanol of second generation.

Different alternatives to convert pulp and paper industry facilities into integrated biorefineries for the production of bioethanol besides paper and energy are possible. Figure 4 schematizes several of those alternatives. Bark and other rejects (e.g., branches, shives, and fine chips), resulting from the starting process of wood preparation through debarking and chipping of wood logs, are usually burned for energy production [95]. Since energy to fuel the pulp mill is already produced by burning the liquor resulting from the pulping process, bark and other rejects could be redirected for ethanol production. Kraft pulping can be applied to these wastes as a pretreatment, producing more energy in the recovery boiler, followed by a subsequent hydrolysis of the pulp obtained, and finally, by the monosaccharides fermentation to produce ethanol. Low-quality and excess pulp resulting from the pulping process could also be redirected for ethanol production. In sulfite pulping mills, as the SSL produced is rich in monosaccharides, it could be fermented to ethanol instead of being completely used for energy production and chemicals recovery. Since the existing paper mills release sludges resulting from the primary and secondary clarifiers and from the paper recycling process, an ethanol production step using those sludges as substrate can be introduced. In addition to paper and ethanol, other products, like textiles, plastics and materials (e.g., cellulose acetate or nitrate) and chemicals (e.g., cellulosic ethers) could be produced from pulp [41].

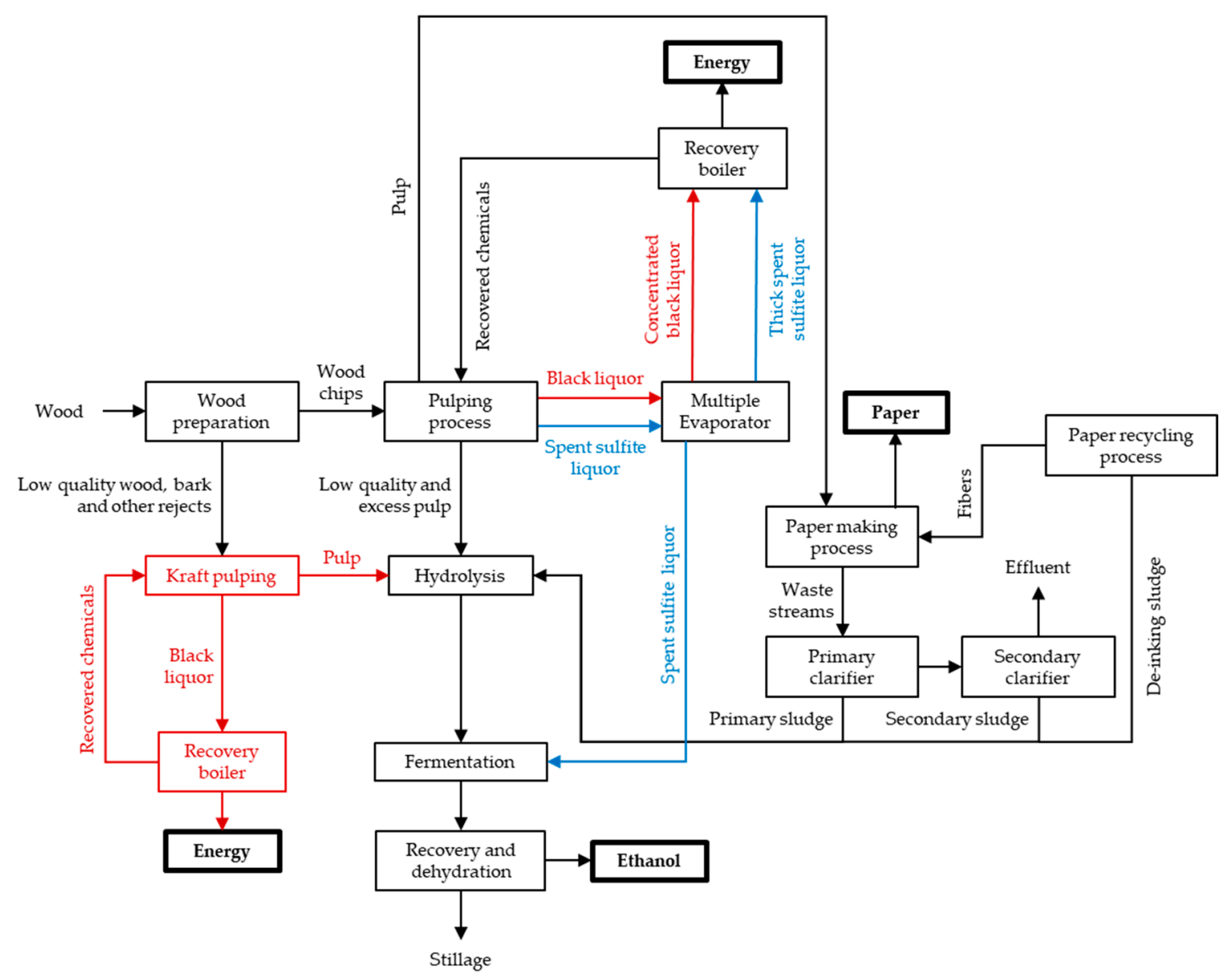

Figure 4. Integration of biorefineries in pulp and paper mills for the production of paper, energy, and second generation bioethanol. Red arrows, boxes and namesexclusive for Kraft pulping mills. Blue arrows and names — exclusive for Sulfite pulping mills. Black arrows, boxes and names—for both pulp and paper mills. 
Besides the development of efficient and low-cost pretreatment technologies and highly efficient fermentation processes, hemicellulose integration is a technological aspect that must also be taken into account when implementing sustainable biorefineries [15]. Furthermore, one of the best approaches to reduce second generation bioethanol production costs is the use of all sugars from LCB, including those from hemicelluloses [80]. Since a key limitation of second generation bioethanol production is the inability of most known natural microorganisms to ferment both hexoses and pentoses successfully [14], the use of co-culture of hexose- and pentose-fermenting yeasts is a potential solution for this problem. This strategy of co-culture is expected to increase the sugars consumption and ethanol production ratios, and consequently, reduce the fermentation time [185]. The use of a co-culture for the production of ethanol from Kraft pulp was already studied, Huang et al. (2017) applied SHF and sequential co-fermentation for the production of ethanol from Phyllostachys heterocycle (bamboo). S. cerevisiae was firstly inoculated and produced $43.5 \mathrm{~g} \cdot \mathrm{L}^{-1}$ of ethanol from glucose, followed by S. stipitis inoculation, producing $11.1 \mathrm{~g} \cdot \mathrm{L}^{-1}$ of ethanol from xylose. Production efficiencies of ethanol from glucose and xylose were 84.4 and $76.6 \%$, respectively [186]. The sequential co-culture aimed to alleviate the repression of xylose consumption in S. stipitis by the availability of glucose.

An alternative for hemicelluloses valorization is to extract hemicelluloses prior to Kraft pulping and to ferment the hydrolysates obtained from ethanol. Mendes et al. (2009) applied autohydrolysis and acid hydrolysis to Eucalyptus globulus wood before Kraft pulping to extract part of the hemicelluloses. The hydrolysates, rich in xylose, were fermented to ethanol by S. stipitis. Acid hydrolysates yielded the higher ethanol concentration of $12 \mathrm{~g} \cdot \mathrm{L}^{-1}$, with an ethanol yield of $0.48 \mathrm{~g} \cdot \mathrm{g}^{-1}$ and a volumetric productivity of $0.22 \mathrm{~g} \cdot \mathrm{L}^{-1} \cdot \mathrm{h}^{-1}$ [187]. Mendes et al. (2011) reported that Eucalyptus globulus hydrolysates that were obtained using autohydrolysis followed by a secondary acid hydrolysis, detoxified with overliming and concentrated, were fermented by S. stipitis providing approximately $10 \mathrm{~g} \cdot \mathrm{L}^{-1}$ of ethanol with a volumetric productivity of $0.23 \mathrm{~g} \cdot \mathrm{L}^{-1} \cdot \mathrm{h}^{-1}$ and an ethanol yield of $0.50 \mathrm{~g} \cdot \mathrm{g}^{-1}$ [188]. Recently, Guigou et al. (2017) utilized green liquor to remove the hemicelluloses from Eucalyptus grandis before the cooking process. The extract obtained was highly concentrated in xylose and it was fermented by S. stipitis. After the removal of inhibitory compounds by using ethyl acetate extraction, the fermentation of the concentrated hydrolysates generated an ethanol concentration of $5.0 \mathrm{~g} \cdot \mathrm{L}^{-1}$, and an ethanol yield of $0.21 \mathrm{~g} \cdot \mathrm{g}^{-1}$ [189]. During the Kraft cooking process, a fraction of hemicelluloses is dissolved in the black liquor and burned in the recovery boiler together with lignin. The supply of energy produced in this process is usually higher than the necessary for the mill. In fact, the combustion of the non-cellulosic compounds produces more energy than the required to maintain the factory. Since hemicelluloses have a relatively low heating value, by removing hemicelluloses before Kraft pulping, the energy balance should not be affected. However, the removal method chosen should not affect the quality of the pulp [190-192]. Therefore, this process seems a promising approach for ethanol production by the conversion of Kraft pulping mills into forest-based biorefineries producing ethanol from hemicelluloses fraction and Kraft pulp from cellulose, as proposed and studied by several authors [189,190,193-195]. Sugars from hemicelluloses can also be used as substrates to produce acetone and butanol, succinic acid, lactic acid, xylooligosaccharides, furfural, and xylitol. In this way, the use of hemicelluloses for the production of value-added compounds in a biorefinery can increase the revenues and the diversity of products obtained [15].

Lignin valorization can be a major technological challenge for integrated biorefineries. Some pulp mills separate and recover lignin due to its market value, since it can be used directly as an end-product or be converted into renewable materials and chemicals [22]. The lignin that is present in the black liquor could be recovered by precipitation with acids, but only in a few mills in the world [38,112]. Lignin can be applied to produce vanillin, cement additive, phenol, carbon fiber, dispersants, adhesives, resins, polymeric foams, and membranes. The use of all components of LCB to produce multiple products in an integrated biorefinery maximizes biomass utilization and minimizes waste generation [15]. LS that is present in SSL could also be extracted and used for the production 
of additives, dispersing agents, binders, vanillin, etc. Additionally, acetic acid, furfural, and other compounds could be separated from the SSL [112].

The total energy yield and economics of a biorefinery could be improved by the co-production of different fuels from a single feedstock [152]. Other possible challenge for the implementation of biorefineries is the stillage, the residues left after separation and purification of ethanol that still present an energetic potential. Hence, the production of biogas through the anaerobic digestion (AD) of these residues is a promising solution to lower the global production costs of bioethanol, since it adds value to the wastes generated [43]. Buzała et al. (2017) suggested that using the residues resulting from the fermentation of Kraft pulp hydrolysate for biogas production by AD is a potential environmentally friendly utilization of those residues [106]. Kemppainen et al. (2012) studied the production of ethanol from paper sludge, followed by the production of biogas from the evaporated residue that is obtained after fermentation [196].

The conversion of pulp and paper mills into integrated biorefineries is encouraged by the successful example of Borregaard company, which runs one of the most advanced biorefineries that is currently in operation in Norway. Borregaard begun producing cellulose pulp in 1889, and in 1938 , it started to produce ethanol from the hemicelluloses of spruce (softwood), mainly mannose, which were present in the SSL resulting from the pulping process. Today, Borregaard has the capacity to produce $20,000 \mathrm{~m}^{3}$ of ethanol annually, making it the largest producer of the second generation ethanol. This biorefinery presents the strategy of producing the maximum number of products out of spruce wood, and today products from cellulose, hemicellulose, and lignin are produced in a larger scale [197]. Borregard biorefinery produces cellulose, ethanol, liquid lignin, lignin powder, vanisperse, vanillin, sodium hypochlorite, hydrochloric acid, chlorine, and steam [198]. Modahl et al. (2015) assessed the environmental impacts that are associated with chemical products of this biorefinery and verified that ethanol production, when compared with results from literature, presents a good performance concerning global warming potential [198].

\section{Future Prospects}

The studies described throughout this review demonstrate the feasibility of producing ethanol from different pulp and paper industry wastes. However, in many studies using Kraft pulp (Table 3), SSL (Table 4), or PPMS (Table 5), the concentrations of ethanol obtained in the fermentation broth were much lower than the recommended minimum of $4 \mathrm{wt} \%$ that is required to have a lower energy demand in the recovery step [93]. The most used method in the recovery of ethanol, distillation, is energy-intensive, accounting for $60-80 \%$ of the total separation cost of bioethanol from water, particularly due to low ethanol concentrations in the fermented broth [94]. The ethanol concentrations that were reported so far would significantly increase the recovery costs. In some cases, ethanol yields and productivities are also low. Hence, it is important to further study new process strategies to improve bioethanol production from the wastes of pulp and paper industry to obtain more efficient bioprocesses with higher yields and productivities.

In most studies concerning ethanol production from Kraft pulp, S. cerevisiae was the microorganism chosen for fermentation. Alternatively, using a hexose- and pentose-fermenting microorganism or a co-culture strategy would allow for the consumption of both hexose and pentose sugars that are present in the hydrolysate, increasing the amount of ethanol produced, as well as the ethanol yield. To the best of our knowledge, the production of ethanol from low-quality Kraft pulp or Kraft pulp obtained from bark and other rejects has not been studied yet. Hence, this seems to be the next step in order to convert Kraft pulp mills into integrated biorefineries.

Production of ethanol from SSSL is being applied since the last century, while using HSSL as a feedstock for ethanol production still faces several challenges. Some technical bottlenecks must be eliminated by developing a microorganism that is able to ferment pentoses in the presence of inhibitors. Also, detoxification techniques that efficiently decrease inhibitors concentrations of HSSL should be developed to be applied at industrial scale. 
The main challenge concerning the use of PPMS as feedstock for bioethanol production is the necessity of a de-ashing step to remove $\mathrm{CaCO}_{3}$, usually achieved using acids, which presents a negative environmental impact. Hence, further studies to develop techniques for the removal of $\mathrm{CaCO}_{3}$ with a decreased environmental impact and improved efficiency are still required to achieve better enzymatic hydrolysis and fermentation.

\section{Conclusions}

The main barrier to the production of LCB second generation bioethanol is the need for a costly and difficult pretreatment due to its characteristic recalcitrance. The pulp and paper industry certainly has one of the biggest incomes of biomass for non-food-chain production, and, at the same time, generates a high amount of residues. Furthermore, the residues resulting from this industry, still rich in monosaccharides or even in polysaccharides, could be used as feedstock for ethanol production. Since pulp and paper industrial plants have a high level of technology, and simultaneously the infrastructures and logistics that are required to fractionate and handle woody biomass, the production of bioethanol must be integrated in all of the industrial pulp mill plants, as well as other processes that could lead to biorefinery implementation and could contribute for changing from the linear to the circular economy model.

Exploiting the technologies and equipment that are already present in the pulp and paper mills to produce ethanol and converting these mills into integrated biorefineries seems promising to valorize the wastes generated and also to diversify the products and to increase the profitability and acceptability of pulp and paper industry. Decreasing investment cost and increasing the opportunity of success of large-scale second generation bioethanol production are other potential advantages of this process integration. The use of all components of LCB (i.e., cellulose, hemicelluloses, and lignin) to produce multiple products in an integrated biorefinery is crucial to maximize biomass valorization and minimize waste generation.

Author Contributions: R.H.R.B. collected the references and wrote the text; L.S.S. supervised the writing and revised the text; A.M.R.B.X. defined the structure and revised the text.

Funding: This work was developed within the scope of the project CICECO-Aveiro Institute of Materials, POCI-01-0145-FEDER-007679 (FCT Ref. UID/CTM/50011/2013), financed by national funds through the FCT/MEC and when appropriate co-financed by FEDER under the PT2020 Partnership Agreement.

Acknowledgments: Authors acknowledge Dmitry Evtyugin for technical advices.

Conflicts of Interest: The authors declare no conflict of interest. The founding sponsors had no role in the design of the study; in the collection, analyses, or interpretation of data; in the writing of the manuscript, and in the decision to publish the results.

\section{References}

1. REN21. Renewables 2017 Global Status Report; REN21 Secretariat: Paris, France, 2017; pp. 30, 48, ISBN 978-3-9818107-6-9.

2. Hussain, A.; Arif, S.M.; Aslam, M. Emerging renewable and sustainable energy technologies: State of the art. Renew. Sustain. Energy Rev. 2017, 71, 12-28. [CrossRef]

3. Du, C.; Zhao, X.; Liu, D.; Lin, C.S.K.; Wilson, K.; Luque, R.; Clark, J. Introduction: An overview of biofuels and production technologies. In Handbook of Biofuels Production Processes and Technologies, 2nd ed.; Lin, C.S.K., Wilson, K., Clark, J., Eds.; Elsevier: Amsterdam, The Netherlands, 2016; p. 3, ISBN 978-0-08-100455-5.

4. Liew, W.H.; Hassim, M.H.; Ng, D.K.S. Review of evolution, technology and sustainability assessments of biofuel production. J. Clean. Prod. 2014, 71, 11-29. [CrossRef]

5. Nigam, P.S.; Singh, A. Production of liquid biofuels from renewable resources. Prog. Energy Combust. Sci. 2011, 37, 52-68. [CrossRef]

6. Azadi, P.; Malina, R.; Barrett, S.R.H.; Kraft, M. The evolution of the biofuel science. Renew. Sustain. Energy Rev. 2017, 76, 1479-1484. [CrossRef] 
7. Balat, M. Production of bioethanol from lignocellulosic materials via the biochemical pathway: A review. Energy Convers. Manag. 2011, 52, 858-875. [CrossRef]

8. Sebayang, A.H.; Masjuki, H.H.; Ong, H.C.; Dharma, S.; Silitonga, A.S.; Mahlia, T.M.I.; Aditiya, H.B. A perspective on bioethanol production from biomass as alternative fuel for spark ignition engine. RSC Adv. 2016, 6, 14964-14992. [CrossRef]

9. Sarris, D.; Papanikolaou, S. Biotechnological production of ethanol: Biochemistry, processes and technologies. Eng. Life Sci. 2016, 16, 307-329. [CrossRef]

10. Maity, S.K. Opportunities, recent trends and challenges of integrated biorefinery: Part II. Renew. Sustain. Energy Rev. 2015, 43, 1446-1466. [CrossRef]

11. Manochio, C.; Andrade, B.R.; Rodriguez, R.P.; Moraes, B.S. Ethanol from biomass: A comparative overview. Renew. Sustain. Energy Rev. 2017, 80, 743-755. [CrossRef]

12. Dutta, K.; Daverey, A.; Lin, J.-G. Evolution retrospective for alternative fuels: First to fourth generation. Renew. Energy 2014, 69, 114-122. [CrossRef]

13. Bastos, R.G. Biofuels from microalgae: Bioethanol. In Energy from Microalgae, 1st ed.; Jacob-Lopes, E., Zepka, L.Q., Queiroz, M.I., Eds.; Springer International Publishing AG: Cham, Switzerland, 2018; p. 229, ISBN 978-3-319-69092-6.

14. Zabed, H.; Sahu, J.N.; Boyce, A.N.; Faruq, G. Fuel ethanol production from lignocellulosic biomass: An overview on feedstocks and technological approaches. Renew. Sustain. Energy Rev. 2016, 66, 751-774. [CrossRef]

15. Yamakawa, C.K.; Qin, F.; Mussatto, S.I. Advances and opportunities in biomass conversion technologies and biorefineries for the development of a bio-based economy. Biomass Bioenergy 2018, 119, 54-60. [CrossRef]

16. Erickson, B. A Rising Tide of Cellulosic Ethanol Production. Ind. Biotechnol. 2018, 14, 77-78. [CrossRef]

17. Phillips, S.; Flach, B.; Lieberz, S.; Lappin, J.; Bolla, S. EU-28 Biofuels Annual: EU Biofuels Annual 2018; USDA: Washington, DC, USA, 2018; pp. 11, 12.

18. Berk, C.; Barros, S. Brazil Biofuels Annual 2018; USDA: Washington, DC, USA, 2018; p. 11.

19. Bajpai, P. Introduction. In Biotechnology for Pulp and Paper Processing, 1st ed.; Springer: New York, NY, USA, 2012; p. 1, ISBN 978-1-4614-1408-7.

20. FAO. Yearbook of Forest Products 2015; Food and Agriculture Organization of the United Nations: Rome, Italy, 2017; ISBN 978-92-5-009766-4.

21. Stoklosa, R.J.; Hodge, D.B. Integration of (hemi)-cellulosic biofuels technologies with chemical pulp production. In Biorefineries: Integrated Biochemical Processes for Liquid Biofuels, 1st ed.; Qureshi, N., Hodge, D., Vertès, A.A., Eds.; Elsevier: Amsterdam, The Netherlands, 2014; p. 74, ISBN 978-0-444-59498-3.

22. Koutinas, A.A.; Vlysidis, A.; Pleissner, D.; Kopsahelis, N.; Lopez Garcia, I.; Kookos, I.K.; Papanikolaou, S.; Kwan, T.H.; Lin, C.S.K. Valorization of industrial waste and by-product streams via fermentation for the production of chemicals and biopolymers. Chem. Soc. Rev. 2014, 43, 2587-2627. [CrossRef] [PubMed]

23. Monrroy, M.; García, J.R.; Mendonça, R.T.; Baeza, J.; Freer, J. Kraft pulping of Eucalyptus globulus as a pretreatment for bioethanol production by simultaneous saccharification and fermentation. J. Chil. Chem. Soc. 2012, 57, 1113-1117. [CrossRef]

24. Phillips, R.B.; Jameel, H.; Chang, H.M. Integration of pulp and paper technology with bioethanol production. Biotechnol. Biofuels 2013, 6, 13. [CrossRef]

25. Pereira, S.R.; Portugal-Nunes, D.J.; Evtuguin, D.V.; Serafim, L.S.; Xavier, A.M.R.B. Advances in ethanol production from hardwood spent sulphite liquors. Process. Biochem. 2013, 48, 272-282. [CrossRef]

26. Schroeder, B.G.; Zanoni, P.R.S.; Magalhães, W.L.E.; Hansel, F.A.; Tavares, L.B.B. Evaluation of biotechnological processes to obtain ethanol from recycled paper sludge. J. Mater. Cycles Waste Manag. 2017, 19, 463-472. [CrossRef]

27. Dugmore, T.I.J.; Clark, J.H.; Bustamante, J.; Houghton, J.A.; Matharu, A.S. Valorisation of biowastes for the production of green materials using chemical methods. Top. Curr. Chem. 2017, 375. [CrossRef]

28. Mohan, S.V.; Nikhil, G.N.; Chiranjeevi, P.; Nagendranatha Reddy, C.; Rohit, M.V.; Kumar, A.N.; Sarkar, O. Waste biorefinery models towards sustainable circular bioeconomy: Critical review and future perspectives. Bioresour. Technol. 2016, 215, 2-12. [CrossRef]

29. IEA Bioenergy. IEA Bioenergy Task42 Biorefining Brochure; IEA Bioenergy: Wageningen, The Netherlands, 2014; pp. 10, 12. 
30. IEA Bioenergy. Newsletter IEA Bioenergy Task42; IEA Bioenergy: Wageningen, The Netherlands, 2017; p. 2.

31. Korhonen, J.; Honkasalo, A.; Seppälä, J. Circular economy: The concept and its limitations. Ecol. Econ. 2018, 143, 37-46. [CrossRef]

32. Seidl, P.R.; Goulart, A.K. Pretreatment processes for lignocellulosic biomass conversion to biofuels and bioproducts. Curr. Opin. Green Sustain. Chem. 2016, 2, 48-53. [CrossRef]

33. Haghighi Mood, S.; Hossein Golfeshan, A.; Tabatabaei, M.; Salehi Jouzani, G.; Najafi, G.H.; Gholami, M.; Ardjmand, M. Lignocellulosic biomass to bioethanol, a comprehensive review with a focus on pretreatment. Renew. Sustain. Energy Rev. 2013, 27, 77-93. [CrossRef]

34. Silveira, M.H.L.; Morais, A.R.C.; da Costa Lopes, A.M.; Olekszyszen, D.N.; Bogel-Łukasik, R.; Andreaus, J.; Pereira Ramos, L. Current pretreatment technologies for the development of cellulosic ethanol and biorefineries. ChemSusChem 2015, 8, 3366-3390. [CrossRef] [PubMed]

35. Chen, H.; Liu, J.; Chang, X.; Chen, D.; Xue, Y.; Liu, P.; Lin, H.; Han, S. A review on the pretreatment of lignocellulose for high-value chemicals. Process Technol. 2017, 160, 196-206. [CrossRef]

36. Sun, S.; Sun, S.; Cao, X.; Sun, R. The role of pretreatment in improving the enzymatic hydrolysis of lignocellulosic materials. Bioresour. Technol. 2016, 199, 49-58. [CrossRef]

37. Stevanovic, T. Chemical composition and properties of wood. In Lignocellulosic Fibers and Wood Handbook, 1st ed.; Belgacem, M.N., Pizzi, A., Eds.; John Wiley \& Sons: Hoboken, NJ, USA, 2016; p. 49, ISBN 978-1-118-77352-9.

38. Ek, M.; Gellerstedt, G.; Henriksson, G. (Eds.) Pulp and Paper Chemistry and Technology, 1st ed.; De Gruyter: Berlin, Germany, 2009; Volume 1, pp. 1-3, 46, 103, 182, 184, 188, ISBN 978-3-11-021339-3.

39. Evtuguin, D.V. Sulphite Pulping. In Lignocellulosic Fibers and Wood Handbook, 1st ed.; Belgacem, M.N., Pizzi, A., Eds.; John Wiley \& Sons: Hoboken, NJ, USA, 2016; pp. 225-229, 233, 239, 240, 243, ISBN 978-1-118-77352-9.

40. Koch, G. Raw material for pulp. In Handbook of Pulp, 1st ed.; Sixta, H., Ed.; Wiley-VCH: Weinheim, Germany, 2006; Volume 1, pp. 22, 31, ISBN 978-3-527-30999-3.

41. Lachenal, D. Kraft pulping. In Lignocellulosic Fibers and Wood Handbook, 1st ed.; Belgacem, M.N., Pizzi, A., Eds.; John Wiley \& Sons: Hoboken, NJ, USA, 2016; pp. 207-209, 213, 215-217, ISBN 978-1-118-77352-9.

42. Nair, R.B.; Lennartsson, P.R.; Taherzadeh, M.J. Bioethanol production from agricultural and municipal wastes. In Current Developments in Biotechnology and Bioengineering-Solid Waste Management, 1st ed.; Wong, J.W.-C., Tyagi, R.D., Pandey, A., Eds.; Elsevier: Amsterdam, The Netherlands, 2017; p. 160, ISBN 978-0-444-63664-5.

43. Rocha, L.; Raud, M.; Orupõld, K.; Kikas, T. Second-generation bioethanol production: A review of strategies for waste valorisation. Agron. Res. 2017, 15, 830-847.

44. Zabed, H.; Sahu, J.N.; Suely, A.; Boyce, A.N.; Faruq, G. Bioethanol production from renewable sources: Current perspectives and technological progress. Renew. Sustain. Energy Rev. 2017, 71, 475-501. [CrossRef]

45. Binod, P.; Pandey, A. Introduction. In Pretreatment of Biomass: Processes and Technologies, 1st ed.; Pandey, A., Negi, S., Binod, P., Larroche, C., Eds.; Elsevier: Amsterdam, The Netherlands, 2015; pp. 3, 5, ISBN 978-0-12-800080-9.

46. Bhutto, A.W.; Qureshi, K.; Harijan, K.; Abro, R.; Abbas, T.; Bazmi, A.A.; Karim, S.; Yu, G. Insight into progress in pre-treatment of lignocellulosic biomass. Energy 2017, 122, 724-745. [CrossRef]

47. Kim, D. Physico-chemical conversion of lignocellulose: Inhibitor effects and detoxification strategies: A mini review. Molecules 2018, 23, 309. [CrossRef]

48. Jönsson, L.J.; Martín, C. Pretreatment of lignocellulose: Formation of inhibitory by-products and strategies for minimizing their effects. Bioresour. Technol. 2016, 199, 103-112. [CrossRef] [PubMed]

49. Ximenes, E.; Kim, Y.; Ladisch, M.R. Biological conversion of plants to fuels and chemicals and the effects of inhibitors. In Aqueous Pretreatment of Plant Biomass for Biological and Chemical Conversion to Fuels and Chemicals: Wyman/Aqueous Pretreatment of Plant Biomass for Biological and Chemical Conversion to Fuels and Chemicals, 1st ed.; Wyman, C.E., Ed.; John Wiley \& Sons, Ltd.: Chichester, UK, 2013; p. 49, ISBN 978-0-470-97583-1.

50. Henriques, T.; Pereira, S.; Serafim, L.; Xavier, A. Two-stage aeration fermentation strategy to improve bioethanol production by Scheffersomyces stipitis. Fermentation 2018, 4, 97. [CrossRef]

51. Ximenes, E.; Kim, Y.; Mosier, N.; Dien, B.; Ladisch, M. Inhibition of cellulases by phenols. Enzyme Microb. Technol. 2010, 46, 170-176. [CrossRef]

52. Amarasekara, A.S. (Ed.) Handbook of Cellulosic Ethanol, 1st ed.; Scrivener Publishing: Beverly, MA, USA, 2014; pp. 284-287, 482, ISBN 978-1-118-23300-9. 
53. Haldar, D.; Sen, D.; Gayen, K. A review on the production of fermentable sugars from lignocellulosic biomass through conventional and enzymatic route-A comparison. Int. J. Green Energy 2016, 13, 1232-1253. [CrossRef]

54. Kuila, A.; Sharma, V.; Garlapati, V.K.; Singh, A.; Roy, L.; Banerjee, R. Present status on enzymatic hydrolysis of lignocellulosic biomass for bioethanol production. In Advances in Biofeedstocks and Biofuels, 1st ed.; Singh, L.K., Chaudhary, G., Eds.; Scrivener Publishing: Beverly, MA, USA, 2016; Volume 1, p. 87, ISBN 978-1-119-11725-4.

55. Verardi, A.; De Bari, I.; Ricca, E.; Calabrò, V. Hydrolysis of lignocellulosic biomass: Current status of processes and technologies and future perspectives. In Bioethanol, 1st ed.; Lima, M.A.P., Ed.; Intech: Rijeka, Croatia, 2012; p. 100, ISBN 978-953-51-0008-9.

56. Kennes, D.; Abubackar, H.N.; Diaz, M.; Veiga, M.C.; Kennes, C. Bioethanol production from biomass: Carbohydrate vs. syngas fermentation. J. Chem. Technol. Biotechnol. 2016, 91, 304-317. [CrossRef]

57. Kamzon, M.A.; Abderafi, S.; Bounahmidi, T. Promising bioethanol processes for developing a biorefinery in the Moroccan sugar industry. Int. J. Hydrog Energy 2016, 41, 20880-20896. [CrossRef]

58. Gupta, A.; Verma, J.P. Sustainable bio-ethanol production from agro-residues: A review. Renew. Sustain. Energy Rev. 2015, 41, 550-567. [CrossRef]

59. Dos Santos, L.V.; de Barros Grassi, M.C.; Gallardo, J.C.M.; Pirolla, R.A.S.; Calderón, L.L.; de Carvalho-Netto, O.V.; Parreiras, L.S.; Camargo, E.L.O.; Drezza, A.L.; Missawa, S.K.; et al. Second-generation ethanol: The need is becoming a reality. Ind. Biotechnol. 2016, 12, 40-57. [CrossRef]

60. Harris, P.V.; Xu, F.; Kreel, N.E.; Kang, C.; Fukuyama, S. New enzyme insights drive advances in commercial ethanol production. Curr. Opin. Chem. Biol. 2014, 19, 162-170. [CrossRef]

61. Gupta, V.K.; Kubicek, C.P.; Berrin, J.-G.; Wilson, D.W.; Couturier, M.; Berlin, A.; Filho, E.X.F.; Ezeji, T. Fungal enzymes for bio-products from sustainable and waste biomass. Trends Biochem. Sci. 2016, 41, 633-645. [CrossRef]

62. Volynets, B.; Ein-Mozaffari, F.; Dahman, Y. Biomass processing into ethanol: Pretreatment, enzymatic hydrolysis, fermentation, rheology, and mixing. Green Process. Synth. 2017, 6, 1-22. [CrossRef]

63. Zhao, X.; Xiong, L.; Zhang, M.; Bai, F. Towards efficient bioethanol production from agricultural and forestry residues: Exploration of unique natural microorganisms in combination with advanced strain engineering. Bioresour. Technol. 2016, 215, 84-91. [CrossRef] [PubMed]

64. Kubicek, C.P.; Kubicek, E.M. Enzymatic deconstruction of plant biomass by fungal enzymes. Curr. Opin. Chem. Biol. 2016, 35, 51-57. [CrossRef] [PubMed]

65. Moreira, L.R.S.; Filho, E.X.F. Insights into the mechanism of enzymatic hydrolysis of xylan. Appl. Microbiol. Biotechnol. 2016, 100, 5205-5214. [CrossRef] [PubMed]

66. Rastogi, M.; Shrivastava, S. Recent advances in second generation bioethanol production: An insight to pretreatment, saccharification and fermentation processes. Renew. Sustain. Energy Rev. 2017, 80, 330-340. [CrossRef]

67. Taherzadeh, M.J.; Lennartsson, P.R.; Teichert, O.; Nordholm, H. Bioethanol production processes. In Biofuels Production, 1st ed.; Babu, V., Thapliyal, A., Patel, G.K., Eds.; Scrivener Publishing: Beverly, MA, USA, 2014; pp. 225, 226, ISBN 978-1-118-63450-9.

68. Kang, Q.; Appels, L.; Tan, T.; Dewil, R. Bioethanol from lignocellulosic biomass: Current findings determine research priorities. Sci. World J. 2014, 2014, 1-13. [CrossRef]

69. Saini, J.K.; Saini, R.; Tewari, L. Lignocellulosic agriculture wastes as biomass feedstocks for second-generation bioethanol production: Concepts and recent developments. 3 Biotech. 2015, 5, 337-353. [CrossRef]

70. Paulova, L.; Patakova, P.; Branska, B.; Rychtera, M.; Melzoch, K. Lignocellulosic ethanol: Technology design and its impact on process efficiency. Biotechnol. Adv. 2015, 33, 1091-1107. [CrossRef]

71. Saggi, S.K.; Dey, P. An overview of simultaneous saccharification and fermentation of starchy and lignocellulosic biomass for bio-ethanol production. Biofuels 2016, 1-13. [CrossRef]

72. Choudhary, J.; Singh, S.; Nain, L. Thermotolerant fermenting yeasts for simultaneous saccharification fermentation of lignocellulosic biomass. Electron. J. Biotechnol. 2016, 21, 82-92. [CrossRef]

73. Aditiya, H.B.; Mahlia, T.M.I.; Chong, W.T.; Nur, H.; Sebayang, A.H. Second generation bioethanol production: A critical review. Renew. Sustain. Energy Rev. 2016, 66, 631-653. [CrossRef]

74. Arora, R.; Behera, S.; Kumar, S. Bioprospecting thermophilic/thermotolerant microbes for production of lignocellulosic ethanol: A future perspective. Renew. Sustain. Energy Rev. 2015, 51, 699-717. [CrossRef] 
75. Limayem, A.; Ricke, S.C. Lignocellulosic biomass for bioethanol production: Current perspectives, potential issues and future prospects. Prog. Energy Combust. Sci. 2012, 38, 449-467. [CrossRef]

76. Den Haan, R.; van Rensburg, E.; Rose, S.H.; Görgens, J.F.; van Zyl, W.H. Progress and challenges in the engineering of non-cellulolytic microorganisms for consolidated bioprocessing. Curr. Opin. Biotechnol. 2015, 33, 32-38. [CrossRef] [PubMed]

77. Liu, H.; Sun, J.; Chang, J.-S.; Shukla, P. Engineering microbes for direct fermentation of cellulose to bioethanol. Crit. Rev. Biotechnol. 2018, 38, 1089-1105. [CrossRef] [PubMed]

78. Yanase, H. Ethanol from bacteria. In Bioprocessing of Renewable Resources to Commodity Bioproducts, 1st ed.; Bisaria, V.S., Kondo, A., Eds.; John Wiley \& Sons, Inc.: Hoboken, NJ, USA, 2014; pp. 184, 185, ISBN 978-1-118-17583-5.

79. Avanthi, A.; Kumar, S.; Sherpa, K.C.; Banerjee, R. Bioconversion of hemicelluloses of lignocellulosic biomass to ethanol: An attempt to utilize pentose sugars. Biofuels 2017, 8, 431-444. [CrossRef]

80. Faraco, V. (Ed.) Lignocellulose Conversion: Enzymatic and Microbial Tools for Bioethanol Production, 1st ed.; Springer: Heidelberg, Germany, 2013; pp. 143, 152, 179, ISBN 978-3-642-37860-7.

81. Sharifyazd, S.; Karimi, K. Effects of fermentation conditions on valuable products of ethanolic fungus Mucor indicus. Electron. J. Biotechnol. 2017, 30, 77-82. [CrossRef]

82. Nair, R.B.; Lundin, M.; Brandberg, T.; Lennartsson, P.R.; Taherzadeh, M.J. Dilute phosphoric acid pretreatment of wheat bran for enzymatic hydrolysis and subsequent ethanol production by edible fungi Neurospora intermedia. Ind. Crop. Prod. 2015, 69, 314-323. [CrossRef]

83. Okamoto, K.; Imashiro, K.; Akizawa, Y.; Onimura, A.; Yoneda, M.; Nitta, Y.; Maekawa, N.; Yanase, H. Production of ethanol by the white-rot basidiomycetes Peniophora cinerea and Trametes suaveolens. Biotechnol. Lett. 2010, 32, 909-913. [CrossRef] [PubMed]

84. Okamoto, K.; Kanawaku, R.; Masumoto, M.; Yanase, H. Efficient xylose fermentation by the brown rot fungus Neolentinus lepideus. Enzyme Microb. Technol. 2012, 50, 96-100. [CrossRef]

85. Okamoto, K.; Uchii, A.; Kanawaku, R.; Yanase, H. Bioconversion of xylose, hexoses and biomass to ethanol by a new isolate of the white rot basidiomycete Trametes versicolor. Springerplus 2014, 3, 121. [CrossRef] [PubMed]

86. Horisawa, S.; Ando, H.; Ariga, O.; Sakuma, Y. Direct ethanol production from cellulosic materials by consolidated biological processing using the wood rot fungus Schizophyllum commune. Bioresour. Technol. 2015, 197, 37-41. [CrossRef] [PubMed]

87. Amore, A.; Faraco, V. Potential of fungi as category I Consolidated BioProcessing organisms for cellulosic ethanol production. Renew. Sustain. Energy Rev. 2012, 16, 3286-3301. [CrossRef]

88. Maehara, T.; Ichinose, H.; Furukawa, T.; Ogasawara, W.; Takabatake, K.; Kaneko, S. Ethanol production from high cellulose concentration by the basidiomycete fungus Flammulina velutipes. Fungal Biol. 2013, 117, 220-226. [CrossRef] [PubMed]

89. Okamoto, K.; Nitta, Y.; Maekawa, N.; Yanase, H. Direct ethanol production from starch, wheat bran and rice straw by the white rot fungus Trametes hirsuta. Enzyme Microb. Technol. 2011, 48, 273-277. [CrossRef] [PubMed]

90. Kamei, I.; Hirota, Y.; Mori, T.; Hirai, H.; Meguro, S.; Kondo, R. Direct ethanol production from cellulosic materials by the hypersaline-tolerant white-rot fungus Phlebia sp. MG-60. Bioresour. Technol. 2012, 112, 137-142. [CrossRef]

91. Paschos, T.; Xiros, C.; Christakopoulos, P. Ethanol effect on metabolic activity of the ethalogenic fungus Fusarium oxysporum. BMC Biotechnol. 2015, 15. [CrossRef] [PubMed]

92. Anasontzis, G.E.; Kourtoglou, E.; Villas-Boâs, S.G.; Hatzinikolaou, D.G.; Christakopoulos, P. Metabolic engineering of Fusarium oxysporum to improve its ethanol-producing capability. Front. Microbiol. $2016,7$. [CrossRef]

93. Galbe, M.; Wallberg, O.; Zacchi, G. Cellulosic bioethanol production. In Separation and Purification Technologies in Biorefineries, 1st ed.; Ramaswamy, S., Huang, H.-J., Ramarao, B.V., Eds.; John Wiley \& Sons Inc.: West Sussex, UK, 2013; pp. 490-493, ISBN 978-0-470-97796-5.

94. Singh, A.; Rangaiah, G.P. Review of technological advances in bioethanol recovery and dehydration. Ind. Eng. Chem. Res. 2017, 56, 5147-5163. [CrossRef] 
95. Heinemann, S.; Blechschmidt, J. Fibrous materials for paper and board manufacture. In Handbook of Paper and Board, 2nd ed.; Holik, H., Ed.; John Wiley \& Sons, Inc.: Hoboken, NJ, USA, 2013; Volume 1, pp. 36-39, 42, 43, ISBN 978-3-527-33184-0.

96. Buzała, K.; Przybysz, P.; Rosicka-Kaczmarek, J.; Kalinowska, H. Production of glucose-rich enzymatic hydrolysates from cellulosic pulps. Cellulose 2015, 22, 663-674. [CrossRef]

97. Solihat, N.N.; Fajriutami, T.; Adi, D.T.N.; Fatriasari, W.; Hermiati, E. Reducing sugar production of sweet sorghum bagasse kraft pulp. In Proceedings of the AIP Conference Proceedings; AIP Publishing: Tangerang Banten, Indonesia, 2017; Volume 1803, p. 020012.

98. Buzała, K.P.; Kalinowska, H.; Przybysz, P.; Małachowska, E. Conversion of various types of lignocellulosic biomass to fermentable sugars using kraft pulping and enzymatic hydrolysis. Wood Sci. Technol. 2017, 51, 873-885. [CrossRef]

99. Troncoso, E.; Castillo, R.; Valenzuela, R.; Reyes, P.; Freer, J.; Norambuena, M.; RodríGuez, J.; Parra, C. Chemical and microstructural changes in Eucalyptus globulus fibers subjected to four different pretreatments and their influence on the enzymatic hydrolysis. J. Chil. Chem. Soc. 2017, 62, 3442-3446. [CrossRef]

100. Huang, C.; He, J.; Min, D.; Lai, C.; Yong, Q. Understanding the nonproductive enzyme adsorption and physicochemical properties of residual lignins in moso bamboo pretreated with sulfuric acid and Kraft pulping. Appl. Biochem. Biotechnol. 2016, 180, 1508-1523. [CrossRef] [PubMed]

101. Novozhilov, E.V.; Sinel'nikov, I.G.; Aksenov, A.S.; Chukhchin, D.G.; Tyshkunova, I.V.; Rozhkova, A.M.; Osipov, D.O.; Zorov, I.N.; Sinitsyn, A.P. Biocatalytic conversion of kraft pulp using cellulase complex of Penicillium verruculosum. Catal. Ind. 2016, 8, 95-100. [CrossRef]

102. Kawaguchi, H.; Katsuyama, Y.; Danyao, D.; Kahar, P.; Nakamura-Tsuruta, S.; Teramura, H.; Wakai, K.; Yoshihara, K.; Minami, H.; Ogino, C.; et al. Caffeic acid production by simultaneous saccharification and fermentation of kraft pulp using recombinant Escherichia coli. Appl. Microbiol. Biotechnol. 2017, 101, 5279-5290. [CrossRef] [PubMed]

103. Kawaguchi, H.; Uematsu, K.; Ogino, C.; Teramura, H.; Niimi-Nakamura, S.; Tsuge, Y.; Hasunuma, T.; Oinuma, K.-I.; Takaya, N.; Kondo, A. Simultaneous saccharification and fermentation of kraft pulp by recombinant Escherichia coli for phenyllactic acid production. Biochem. Eng. J. 2014, 88, 188-194. [CrossRef]

104. Hama, S.; Mizuno, S.; Kihara, M.; Tanaka, T.; Ogino, C.; Noda, H.; Kondo, A. Production of D-lactic acid from hardwood pulp by mechanical milling followed by simultaneous saccharification and fermentation using metabolically engineered Lactobacillus plantarum. Bioresour. Technol. 2015, 187, 167-172. [CrossRef] [PubMed]

105. Ko, C.-H.; Wang, Y.-N.; Chang, F.-C.; Chen, J.-J.; Chen, W.-H.; Hwang, W.-S. Potentials of lignocellulosic bioethanols produced from hardwood in Taiwan. Energy 2012, 44, 329-334. [CrossRef]

106. Buzała, K.P.; Kalinowska, H.; Małachowska, E.; Przybysz, P. The utility of selected kraft hardwood and softwood pulps for fuel ethanol production. Ind. Crop. Prod. 2017, 108, 824-830. [CrossRef]

107. Wistara, N.J.; Pelawi, R.; Fatriasari, W. The effect of lignin content and freeness of pulp on the bioethanol productivity of Jabon wood. Waste Biomass Valorization 2016, 7, 1141-1146. [CrossRef]

108. Edgardo, A.; Carolina, P.; Manuel, R.; Juanita, F.; Baeza, J. Selection of thermotolerant yeast strains Saccharomyces cerevisiae for bioethanol production. Enzyme Microb. Technol. 2008, 43, 120-123. [CrossRef]

109. Bauer, N.A.; Gibbons, W.R. Saccharification versus simultaneous saccharification and fermentation of kraft pulp. Biol. Eng. 2012, 5, 48-55. [CrossRef]

110. Amoah, J.; Ishizue, N.; Ishizaki, M.; Yasuda, M.; Takahashi, K.; Ninomiya, K.; Yamada, R.; Kondo, A.; Ogino, C. Development and evaluation of consolidated bioprocessing yeast for ethanol production from ionic liquid-pretreated bagasse. Bioresour. Technol. 2017, 245, 1413-1420. [CrossRef] [PubMed]

111. Sixta, H.; Potthast, A.; Krotschek, A.W. Chemical pulping processes. In Handbook of Pulp, 1st ed.; Sixta, H., Ed.; Wiley-VCH: Weinheim, Germany, 2006; Volume 1, pp. 392, 393, 407, 418, 419, ISBN 978-3-527-30999-3.

112. Sjöström, E. Wood Chemistry: Fundamentals and Applications, 2nd ed.; Academic Press: San Diego, CA, USA, 1993; pp. 137, 138, 158, 238, 240, 244, ISBN 978-0-12-647481-7.

113. Portugal-Nunes, D.; Sànchez i Nogué, V.; Pereira, S.R.; Craveiro, S.C.; Calado, A.J.; Xavier, A.M. Effect of cell immobilization and $\mathrm{pH}$ on Scheffersomyces stipitis growth and fermentation capacity in rich and inhibitory media. Bioresour. Bioprocess. 2015, 2. [CrossRef]

114. Nigam, J.N. Ethanol production from hardwood spent sulfite liquor using an adapted strain of Pichia stipitis. J. Ind. Microbiol. Biotechnol. 2001, 26, 145-150. [CrossRef] [PubMed] 
115. Rueda, C.; Calvo, P.A.; Moncalián, G.; Ruiz, G.; Coz, A. Biorefinery options to valorize the spent liquor from sulfite pulping. J. Chem. Technol. Biotechnol. 2015, 90, 2218-2226. [CrossRef]

116. Rueda, C.; Marinova, M.; Paris, J.; Ruiz, G.; Coz, A. Technoeconomic assessment of different biorefinery approaches for a spent sulfite liquor. J. Chem. Technol. Biotechnol. 2016, 91, 2646-2653. [CrossRef]

117. Queirós, D.; Rossetti, S.; Serafim, L.S. PHA production by mixed cultures: A way to valorize wastes from pulp industry. Bioresour. Technol. 2014, 157, 197-205. [CrossRef]

118. Queirós, D.; Fonseca, A.; Lemos, P.C.; Serafim, L.S. Long-term operation of a two-stage polyhydroxyalkanoates production process from hardwood sulphite spent liquor. J. Chem. Technol. Biotechnol. 2016, 91, 2480-2487. [CrossRef]

119. Queirós, D.; Sousa, R.; Pereira, S.; Serafim, L.S. Valorization of a pulp industry by-product through the production of short-chain organic acids. Fermentation 2017, 3, 20. [CrossRef]

120. Figueira, D.; Cavalheiro, J.; Ferreira, B. Purification of polymer-grade fumaric acid from fermented spent sulfite liquor. Fermentation 2017, 3, 13. [CrossRef]

121. Linden, T.; Hahn-Higerdal, B. Fermentation of lignocellulose hydrolysates with yeasts and xylose isomerase. Enzyme Microb. Technol. 1989, 11, 337-353. [CrossRef]

122. Safi, B.F.; Rouleau, D.; Mayer, R.C.; Desrochers, M. Fermentation kinetics of spent sulfite liquor by Saccharomyces cerevisiae. Biotechnol. Bioeng. 1986, 28, 944-951. [CrossRef] [PubMed]

123. Mandenius, C.F. Controlling fermentation of lignocellulose hydrolysates in a continuous hollow-fiber reactor using biosensors. Biotechnol. Bioeng. 1988, 32, 123-129. [CrossRef] [PubMed]

124. Björling, T.; Lindman, B. Evaluation of xylose-fermenting yeasts for ethanol production from spent sulfite liquor. Enzyme Microb. Technol. 1989, 11, 240-246. [CrossRef]

125. Yu, S.; Wayman, M.; Parekh, S.K. Fermentation to ethanol of pentose-containing spent sulphite liquor. Biotechnol. Bioeng. 1987, 29, 1144-1150. [CrossRef] [PubMed]

126. Olsson, L.; Hahn-Hägerdal, B. Fermentative performance of bacteria and yeasts in lignocellulose hydrolysates. Process. Biochem. 1993, 28, 249-257. [CrossRef]

127. Lawford, H.G.; Rousseau, J.D. Production of ethanol from pulp mill hardwood and softwood spent sulfite liquors by genetically engineered E. coli. Appl. Biochem. Biotechnol. 1993, 39-40, 667-685. [CrossRef]

128. Marko-Varga, G.; Buttler, T.; Gorton, L.; Olsson, L.; Durand, G.; Barceló, D. Qualitative and quantitative carbohydrate analysis of fermentation substrates and broths by liquid chromatographic techniques. J. Chromatogr. A 1994, 665, 317-332. [CrossRef]

129. Mohandas, D.V.; Whelan, D.R.; Panchal, C.J. Development of xylose-fermenting yeasts for ethanol production at high acetic acid concentrations. Appl. Biochem. Biotechnol. 1995, 51-52, 307-318. [CrossRef]

130. Schneider, H. Selective removal of acetic acid from hardwood-spent sulfite liquor using a mutant yeast. Enzyme Microb. Technol. 1996, 19, 94-98. [CrossRef]

131. Palmqvist, E.; Galbe, M.; Hahn-Hägerdal, B. Evaluation of cell recycling in continuous fermentation of enzymatic hydrolysates of spruce with Saccharomyces cerevisiae and on-line monitoring of glucose and ethanol. Appl. Microbiol. Biotechnol. 1998, 50, 545-551. [CrossRef] [PubMed]

132. Harner, N.K.; Bajwa, P.K.; Formusa, P.A.; Austin, G.D.; Habash, M.B.; Trevors, J.T.; Chan, C.-K.; Ho, C.-Y.; Lee, H. Determinants of tolerance to inhibitors in hardwood spent sulfite liquor in genome shuffled Pachysolen tannophilus strains. Antonie Van Leeuwenhoek 2015, 108, 811-834. [CrossRef] [PubMed]

133. Pereira, S.R.; Sànchez i Nogué, V.; Frazão, C.J.R.; Serafim, L.S.; Gorwa-Grauslund, M.F.; Xavier, A.M.R.B. Adaptation of Scheffersomyces stipitis to hardwood spent sulfite liquor by evolutionary engineering. Biotechnol. Biofuels 2015, 8. [CrossRef] [PubMed]

134. Takahashi, S.; Tanifuji, K.; Shiell, K.; Fatehi, P.; Jahan, M.S.; Ohi, H.; Ni, Y. Removal of acetic acid from spent sulfite liquor using anion exchange resin for effective xylose fermentation with Pichia stipitis. Bioresources 2013, 8. [CrossRef]

135. Pereira, S.R.; Ivanuša, Š.; Evtuguin, D.V.; Serafim, L.S.; Xavier, A.M.R.B. Biological treatment of eucalypt spent sulphite liquors: A way to boost the production of second generation bioethanol. Bioresour. Technol. 2012, 103, 131-135. [CrossRef] [PubMed]

136. Pinel, D.; D'Aoust, F.; del Cardayre, S.B.; Bajwa, P.K.; Lee, H.; Martin, V.J.J. Saccharomyces cerevisiae genome shuffling through recursive population mating leads to improved tolerance to spent sulfite liquor. Appl. Environ. Microbiol. 2011, 77, 4736-4743. [CrossRef] [PubMed] 
137. Bajwa, P.K.; Pinel, D.; Martin, V.J.J.; Trevors, J.T.; Lee, H. Strain improvement of the pentose-fermenting yeast Pichia stipitis by genome shuffling. J. Microbiol. Methods 2010, 81, 179-186. [CrossRef]

138. Xavier, A.M.R.B.; Correia, M.F.; Pereira, S.R.; Evtuguin, D.V. Second-generation bioethanol from eucalypt sulphite spent liquor. Bioresour. Technol. 2010, 101, 2755-2761. [CrossRef]

139. Bajwa, P.K.; Shireen, T.; D'Aoust, F.; Pinel, D.; Martin, V.J.J.; Trevors, J.T.; Lee, H. Mutants of the pentosefermenting yeast Pichia stipitis with improved tolerance to inhibitors in hardwood spent sulfite liquor. Biotechnol. Bioeng. 2009, 104, 892-900. [CrossRef]

140. Johansson, E.; Xiros, C.; Larsson, C. Fermentation performance and physiology of two strains of Saccharomyces cerevisiae during growth in high gravity spruce hydrolysate and spent sulphite liquor. BMC Biotechnol. 2014, 14, 47. [CrossRef] [PubMed]

141. Guo, Z.; Olsson, L. Characterization and fermentation of side streams from sulfite pulping. Process. Biochem. 2014, 49, 1231-1237. [CrossRef]

142. Tanifuji, K.; Takahashi, S.; Shiell, K.; Jahan, S.M.; Ni, Y.; Ohi, H. Improvement of ethanol fermentation from oligosaccharides in spent sulfite liquor with Pichia stipitis by combined calcium oxide and ion exchange resin treatments. Bioresources 2013, 8. [CrossRef]

143. Johansson, E.; Brandberg, T.; Larsson, C. Influence of cultivation procedure for Saccharomyces cerevisiae used as pitching agent in industrial spent sulphite liquor fermentations. J. Ind. Microbiol. Biotechnol. 2011, 38, 1787-1792. [CrossRef] [PubMed]

144. Novy, V.; Krahulec, S.; Longus, K.; Klimacek, M.; Nidetzky, B. Co-fermentation of hexose and pentose sugars in a spent sulfite liquor matrix with genetically modified Saccharomyces cerevisiae. Bioresour. Technol. 2013, 130, 439-448. [CrossRef] [PubMed]

145. Keating, J.D.; Robinson, J.; Cotta, M.A.; Saddler, J.N.; Mansfield, S.D. An ethanologenic yeast exhibiting unusual metabolism in the fermentation of lignocellulosic hexose sugars. J. Ind. Microbiol. Biotechnol. 2004, 31, 235-244. [CrossRef] [PubMed]

146. Keating, J.D.; Panganiban, C.; Mansfield, S.D. Tolerance and adaptation of ethanologenic yeasts to lignocellulosic inhibitory compounds. Biotechnol. Bioeng. 2006, 93, 1196-1206. [CrossRef]

147. Helle, S.S.; Murray, A.; Lam, J.; Cameron, D.R.; Duff, S.J. Xylose fermentation by genetically modified Saccharomyces cerevisiae 259ST in spent sulfite liquor. Bioresour. Technol. 2004, 92, 163-171. [CrossRef]

148. Fernandes, D.L.A.; Pereira, S.R.; Serafim, L.S.; Evtuguin, D.V.; Xavier, A.M.R.B. Second generation bioethanol from lignocellulosics: Processing of hardwood sulphite spent liquor. In Bioethanol, 1st ed.; Intech: Rijeka, Croatia, 2012; pp. 133, 134, ISBN 978-953-51-0008-9.

149. Fernandes, D.L.A.; Silva, C.M.; Xavier, A.M.R.B.; Evtuguin, D.V. Fractionation of sulphite spent liquor for biochemical processing using ion exchange resins. J. Biotechnol. 2012, 162, 415-421. [CrossRef]

150. Das, T.K.; Jain, A.K. Pollution prevention advances in pulp and paper processing. Environ. Prog. 2001, 20, 87-92. [CrossRef]

151. Faubert, P.; Barnabé, S.; Bouchard, S.; Côté, R.; Villeneuve, C. Pulp and paper mill sludge management practices: What are the challenges to assess the impacts on greenhouse gas emissions? Resour. Conserv. Recycl. 2016, 108, 107-133. [CrossRef]

152. Gottumukkala, L.D.; Haigh, K.; Collard, F.-X.; van Rensburg, E.; Görgens, J. Opportunities and prospects of biorefinery-based valorisation of pulp and paper sludge. Bioresour. Technol. 2016, 215, 37-49. [CrossRef] [PubMed]

153. Boshoff, S.; Gottumukkala, L.D.; van Rensburg, E.; Görgens, J. Paper sludge (PS) to bioethanol: Evaluation of virgin and recycle mill sludge for low enzyme, high-solids fermentation. Bioresour. Technol. 2016, 203, 103-111. [CrossRef] [PubMed]

154. Kuokkanen, T.; Nurmesniemi, H.; Pöykiö, R.; Kujala, K.; Kaakinen, J.; Kuokkanen, M. Chemical and leaching properties of paper mill sludge. Chem. Speciat. Bioavailab. 2008, 20, 111-122. [CrossRef]

155. Meyer, T.; Edwards, E.A. Anaerobic digestion of pulp and paper mill wastewater and sludge. Water Res. 2014, 65, 321-349. [CrossRef] [PubMed]

156. Monte, M.C.; Fuente, E.; Blanco, A.; Negro, C. Waste management from pulp and paper production in the European Union. Waste Manag. 2009, 29, 293-308. [CrossRef] [PubMed] 
157. Mendes, C.V.T.; Rocha, J.M.; dos, S.; de Menezes, F.F.; Carvalho, M.; da, G.V.S. Batch and fed-batch simultaneous saccharification and fermentation of primary sludge from pulp and paper mills. Environ. Technol. 2017, 38, 1498-1506. [CrossRef]

158. Gogoi, H.; Nirosha, V.; Jayakumar, A.; Prabhu, K.; Maitra, M.; Panjanathan, R. Paper mill sludge as a renewable substrate for the production of acetone-butanol-ethanol using Clostridium sporogenes NCIM 2337. Energy Sources Part A Recover. Util. Environ. Eff. 2018, 40, 39-44. [CrossRef]

159. Guan, W.; Shi, S.; Tu, M.; Lee, Y.Y. Acetone-butanol-ethanol production from Kraft paper mill sludge by simultaneous saccharification and fermentation. Bioresour. Technol. 2016, 200, 713-721. [CrossRef]

160. Moreau, A.; Montplaisir, D.; Sparling, R.; Barnabé, S. Hydrogen, ethanol and cellulase production from pulp and paper primary sludge by fermentation with Clostridium thermocellum. Biomass Bioenergy 2015, 72, 256-262. [CrossRef]

161. Wang, W.; Kang, L.; Lee, Y.Y. Production of cellulase from Kraft paper mill sludge by Trichoderma Reesei Rut C-30. Appl. Biochem. Biotechnol. 2010, 161, 382-394. [CrossRef] [PubMed]

162. Kolbl, S.; Forte-Tavčer, P.; Stres, B. Potential for valorization of dehydrated paper pulp sludge for biogas production: Addition of selected hydrolytic enzymes in semi-continuous anaerobic digestion assays. Energy 2017, 126, 326-334. [CrossRef]

163. Steffen, F.; Janzon, R.; Wenig, F.; Saake, B. Valorization of waste streams from deinked pulp mills through anaerobic digestion of deinking sludge. Bioresources 2017, 12. [CrossRef]

164. Ridout, A.; Boshoff, S.; Haigh, K.; Carrier, M.; Van, E.; Görgens, J. Valorisation of paper waste sludge via fermentation and pyrolysis. Cellul. Chem. Technol. 2016, 50, 439-442.

165. Reckamp, J.M.; Garrido, R.A.; Satrio, J.A. Selective pyrolysis of paper mill sludge by using pretreatment processes to enhance the quality of bio-oil and biochar products. Biomass Bioenergy 2014, 71, 235-244. [CrossRef]

166. Jain, S.; Chouhan, S.; Chavan, K.J.; Singh, P.; Tiwari, A. Bioethanol production from waste paper sludge as a fermentation substrate by using xylose fermenting yeast. Minerva Biotecnol. 2016, $28,7$.

167. Gurram, R.N.; Al-Shannag, M.; Lecher, N.J.; Duncan, S.M.; Singsaas, E.L.; Alkasrawi, M. Bioconversion of paper mill sludge to bioethanol in the presence of accelerants or hydrogen peroxide pretreatment. Bioresour. Technol. 2015, 192, 529-539. [CrossRef]

168. Mendes, C.V.T.; Rocha, J.M.S.; Carvalho, M.G.V.S. Valorization of residual streams from pulp and paper mills: Pretreatment and bioconversion of primary sludge to bioethanol. Ind. Eng. Chem. Res. 2014, 53, 19398-19404. [CrossRef]

169. Marques, S.; Alves, L.; Roseiro, J.C.; Gírio, F.M. Conversion of recycled paper sludge to ethanol by SHF and SSF using Pichia stipitis. Biomass Bioenergy 2008, 32, 400-406. [CrossRef]

170. Mendes, C.V.T.; Cruz, C.H.G.; Reis, D.F.N.; Carvalho, M.G.V.S.; Rocha, J.M.S. Integrated bioconversion of pulp and paper primary sludge to second generation bioethanol using Saccharomyces cerevisiae ATCC 26602. Bioresour. Technol. 2016, 220, 161-167. [CrossRef]

171. Peng, L.; Chen, Y. Conversion of paper sludge to ethanol by separate hydrolysis and fermentation (SHF) using Saccharomyces cerevisiae. Biomass Bioenergy 2011, 35, 1600-1606. [CrossRef]

172. Pelli, P.; Haapala, A.; Pykäläinen, J. Services in the forest-based bioeconomy-Analysis of European strategies. Scand. J. For. Res. 2017, 32, 559-567. [CrossRef]

173. Wu, S.; Chang, H.; Phillips, R.; Jameel, H. Techno-economic analysis of the optimum softwood lignin content for the production of bioethanol in a repurposed Kraft mill. Bioresources 2014, 9. [CrossRef]

174. Fornell, R.; Berntsson, T. Process integration study of a kraft pulp mill converted to an ethanol production plant-Part A: Potential for heat integration of thermal separation units. Appl. Therm. Eng. 2012, 35, 81-90. [CrossRef]

175. Fornell, R.; Berntsson, T.; Åsblad, A. Process integration study of a kraft pulp mill converted to an ethanol production plant-Part B: Techno-economic analysis. Appl. Therm. Eng. 2012, 42, 179-190. [CrossRef]

176. Petersen, A.M.; Daful, A.G.; Görgens, J.F. Technical, economic, and greenhouse gas reduction potential of combined ethanol fermentation and biofuel gasification-synthesis at sulphite pulping mills. Energy Fuels 2016, 30, 7387-7399. [CrossRef] 
177. Petersen, A.M.; Haigh, K.; Görgens, J.F. Techno-economics of integrating bioethanol production from spent sulfite liquor for reduction of greenhouse gas emissions from sulfite pulping mills. Biotechnol. Biofuels 2014, 7. [CrossRef]

178. Fan, Z.; Lynd, L.R. Conversion of paper sludge to ethanol, II: Process design and economic analysis. Bioprocess. Biosyst. Eng. 2007, 30, 35-45. [CrossRef]

179. Aksoy, B.; Cullinan, H.; Webster, D.; Gue, K.; Sukumaran, S.; Eden, M.; Sammons, N. Woody biomass and mill waste utilization opportunities in Alabama: Transportation cost minimization, optimum facility location, economic feasibility, and impact. Environ. Prog. Sustain. Energy 2011, 30, 720-732. [CrossRef]

180. Machani, M.; Nourelfath, M.; D'Amours, S. A mathematically-based framework for evaluating the technical and economic potential of integrating bioenergy production within pulp and paper mills. Biomass Bioenergy 2014, 63, 126-139. [CrossRef]

181. Wang, L.; Wang, J.G.; Littlewood, J.; Cheng, H.B. Co-production of biorefinery products from kraft paper sludge and agricultural residues: Opportunities and challenges. Green Chem. 2014, 16, 1527. [CrossRef]

182. Chen, H.; Venditti, R.; Gonzalez, R.; Phillips, R.; Jameel, H.; Park, S. Economic evaluation of the conversion of industrial paper sludge to ethanol. Energy Econ. 2014, 44, 281-290. [CrossRef]

183. Robus, C.L.L.; Gottumukkala, L.D.; van Rensburg, E.; Görgens, J.F. Feasible process development and techno-economic evaluation of paper sludge to bioethanol conversion: South African paper mills scenario. Renew. Energy 2016, 92, 333-345. [CrossRef]

184. Sebastião, D.; Gonçalves, M.S.; Marques, S.; Fonseca, C.; Gírio, F.; Oliveira, A.C.; Matos, C.T. Life cycle assessment of advanced bioethanol production from pulp and paper sludge. Bioresour. Technol. 2016, 208, 100-109. [CrossRef] [PubMed]

185. Chen, Y. Development and application of co-culture for ethanol production by co-fermentation of glucose and xylose: A systematic review. J. Ind. Microbiol. Biotechnol. 2011, 38, 581-597. [CrossRef] [PubMed]

186. Huang, C.; He, J.; Chang, H.; Jameel, H.; Yong, Q. Coproduction of ethanol and lignosulfonate from moso bamboo residues by fermentation and sulfomethylation. Waste Biomass Valorization 2017, 8, 965-974. [CrossRef]

187. Mendes, C.V.T.; Carvalho, M.G.V.S.; Baptista, C.M.S.G.; Rocha, J.M.S.; Soares, B.I.G.; Sousa, G.D.A. Valorisation of hardwood hemicelluloses in the kraft pulping process by using an integrated biorefinery concept. Food Bioprod. Process. 2009, 87, 197-207. [CrossRef]

188. Mendes, C.V.T.; Rocha, J.M.S.; Soares, B.I.G.; Sousa, G.D.A.; Carvalho, M.G.V.S. Extraction of hemicelluloses prior to kraft cooking: A step for an integrated biorefinery in the pulp mill. O Pap. 2011, 72, 79-83.

189. Guigou, M.D.; Cebreiros, F.; Cabrera, M.N.; Ferrari, M.D.; Lareo, C. Bioethanol production from Eucalyptus grandis hemicellulose recovered before kraft pulping using an integrated biorefinery concept. Biomass Convers. Biorefinery 2017, 7, 191-197. [CrossRef]

190. Boucher, J.; Chirat, C.; Lachenal, D. Extraction of hemicelluloses from wood in a pulp biorefinery, and subsequent fermentation into ethanol. Energy Convers. Manag. 2014, 88, 1120-1126. [CrossRef]

191. Cabrera, M.N.; Arrosbide, M.F.; Franzoni, P.; Cassella, N. Integrated forest biorefineries: Green liquor extraction in eucalyptus wood prior to kraft pulping. Biomass Convers. Biorefinery 2016, 6, 465-474. [CrossRef]

192. Martin-Sampedro, R.; Eugenio, M.E.; Moreno, J.A.; Revilla, E.; Villar, J.C. Integration of a kraft pulping mill into a forest biorefinery: Pre-extraction of hemicellulose by steam explosion versus steam treatment. Bioresour. Technol. 2014, 153, 236-244. [CrossRef] [PubMed]

193. Huang, H.-J.; Ramaswamy, S.; Al-Dajani, W.W.; Tschirner, U. Process modeling and analysis of pulp mill-based integrated biorefinery with hemicellulose pre-extraction for ethanol production: A comparative study. Bioresour. Technol. 2010, 101, 624-631. [CrossRef] [PubMed]

194. Moshkelani, M.; Marinova, M.; Perrier, M.; Paris, J. The forest biorefinery and its implementation in the pulp and paper industry: Energy overview. Appl. Therm. Eng. 2013, 50, 1427-1436. [CrossRef]

195. Lundberg, V.; Axelsson, E.; Mahmoudkhani, M.; Berntsson, T. Process integration of near-neutral hemicellulose extraction in a Scandinavian kraft pulp mill-Consequences for the steam and $\mathrm{Na} / \mathrm{S}$ balances. Appl. Therm. Eng. 2012, 43, 42-50. [CrossRef]

196. Kemppainen, K.; Ranta, L.; Sipilä, E.; Östman, A.; Vehmaanperä, J.; Puranen, T.; Langfelder, K.; Hannula, J.; Kallioinen, A.; Siika-aho, M.; et al. Ethanol and biogas production from waste fibre and fibre sludge-The FibreEtOH concept. Biomass Bioenergy 2012, 46, 60-69. [CrossRef] 
197. Rødsrud, G.; Lersch, M.; Sjöde, A. History and future of world's most advanced biorefinery in operation. Biomass Bioenergy 2012, 46, 46-59. [CrossRef]

198. Modahl, I.S.; Brekke, A.; Valente, C. Environmental assessment of chemical products from a Norwegian biorefinery. J. Clean. Prod. 2015, 94, 247-259. [CrossRef] 